Article

\title{
Chemical Profile, Antioxidant, Anti-Inflammatory, and Anti-Cancer Effects of Italian Salvia rosmarinus Spenn. Methanol Leaves Extracts
}

\author{
Matteo Brindisi ${ }^{1}\left(\mathbb{D}\right.$, Chouaha Bouzidi $^{2}$, Luca Frattaruolo ${ }^{1}$, Monica R. Loizzo ${ }^{1}(\mathbb{D}$, \\ Rosa Tundis ${ }^{1, *(\mathbb{D}}$, Annabelle Dugay ${ }^{2}$, Brigitte Deguin ${ }^{2}$, Anna Rita Cappello ${ }^{1}$ \\ and Maria Stella Cappello ${ }^{3}$ \\ 1 Department of Pharmacy, Health and Nutritional Sciences, University of Calabria, Via Pietro Bucci, \\ 87036 Rende (CS), Italy; matteo.brindisi@unical.it (M.B.); luca.frattaruolo@unical.it (L.F.); \\ monica_rosa.loizzo@unical.it (M.R.L.); annarita.cappello@unical.it (A.R.C.) \\ 2 Faculté de Pharmacie de Paris, Université de Paris, U.M.R. n 8038, -CiTCoM (CNRS, Université de Paris), \\ 75006 Paris, France; chouaha.bouzidi@parisdescartes.fr (C.B.); annabelle.dugay@parisdescartes.fr (A.D.); \\ brigitte.deguin@parisdescartes.fr (B.D.) \\ 3 National Research Council (CNR), Institute of Science of Food Production (ISPA), Prov. le Lecce-Monteroni, \\ 73100 Lecce, Italy; maristella.cappello@ispa.cnr.it \\ * Correspondence: rosa.tundis@unical.it; Tel.: +39-0984-493-246
}

Received: 30 July 2020; Accepted: 2 September 2020; Published: 3 September 2020

\begin{abstract}
In this study, we evaluated and compared the chemical composition, the antioxidant, anti-inflammatory, and anti-proliferative effects of four methanol extracts (R1-R4), of Salvia rosmarinus Spenn. in two different sites of Southern Italy obtained by maceration or ultrasound-assisted extraction. Extracts of S. rosmarinus collected on the Ionian coast are indicated with the abbreviations R1 (maceration) and R2 (ultrasound-assisted extraction). Extracts of S. rosmarinus collected on the Tyrrhenian coast are indicated with the abbreviations R3 (maceration) and R4 (ultrasound-assisted extraction). The chemical composition was analyzed using High Pressure liquid chromatography-Diod-Array detection-Electrospray ionization-Quadrupole-Mass Spectroscopy (HPLC-DAD-ESI-Q-MS). The antioxidant activity was analyzed by $2,2^{\prime}$-azino-bis(3-ethylbenzothiazoline-6-sulphonic acid) (ABTS) 2,2-diphenyl-1-picrylhydrazyl (DPPH), $\beta$-carotene bleaching, and Ferric Reducing Antioxidant Power (FRAP) assays. Antioxidant features were also assessed in lipopolysaccharide (LPS)-stimulated RAW-264.7 murine macrophages, evaluating Reactive Oxygen Species (ROS) production; in the same experimental model, the anti-inflammatory activity of the extracts was investigated. Interestingly, all extracts displayed antioxidant and anti-inflammatory properties. They exhibited significative nitrite production inhibitory activity, whith $\mathrm{IC}_{50}$ values ranging from 3.46 to $5.53 \mu \mathrm{g} / \mathrm{mL}$, without impairing cell viability. The anti-inflammatory activity was also investigated by Western Blotting and immunofluorescence assay, highlighting the R3 and R4 extracts ability to reduce NF- $\mathrm{KB}$ translocation, as well as to disrupt the MAPKs signaling pathway. Extracts exhibited both potential anti-proliferative activity on breast cancer cells, inducing apoptosis, without affecting non-tumorigenic cells, and the ability to inhibit MDA-MB-231 cells' motility. Finally, the rosemary extracts treatment significantly reduced the power of conditioned media, from MCF-7 or MDA-MB-231 cells to induce nitrite production on RAW 264.7 cells, confirming their promising anti-inflammatory activity.
\end{abstract}

Keywords: rosemary; extraction procedures; high pressure liquid chromatography-diod-array detection-electrospray ionization-quadrupole-mass spectroscopy (HPLC-DAD-ESI-Q-MS); antioxidant activity; anti-inflammatory activity; NF-kB/MAPK pathway; anti-cancer activity 


\section{Introduction}

Cancer is nowadays one of the biggest health problems in the world. In particular, breast cancer is the most common type of carcinoma in women and represents their major cause of death worldwide [1]. Tumor in general, as well as the breast cancer, is characterized by an aberrant growth and ability to invade and metastasize different tissues and organs along the organism [2,3]. Numerous can be the causes that determine the neoplastic event onset, a series of more or less important events that ultimately determine the subversion of the cell that goes from being healthy to a cancer cell [4-6]. In recent years a close correlation between oxidative stress and cancer has been observed [7,8]. Indeed, a massive presence of oxygen free radicals [9] can determine important changes in the cell favoring a cancer phenotype onset and, therefore, giving way to the cancer process $[10,11]$. However, in addition to oxidative stress, the carcinogenesis process may be due to an inflammatory process [12,13]. The inflammatory process is one of the processes that the body sets in motion as protective mechanism against pathogens or even tissue damage in order to facilitate its repair. However, if this process is prolonged over time it causes a chronic inflammation of the tissue which can determine the onset of a neoplastic event [14]. Indeed, there are several cancers associated with inflammatory processes such as colorectal cancer, prostate cancer, and many others [15-17].

Given the large number of breast cancer cases diagnosed worldwide and given the different causes and characteristics that distinguish breast cancers, researchers are asked to continuously identify new therapeutic targets and new drugs that can hit this pathology.

As pointed out recently, natural products from medicinal plants represent a fertile ground for the development of novel anti-cancer agents [18,19]. Indeed, natural products very often are less toxic than synthetic products and contain within them various potential activities especially if we refer to the phytocomplex, in which different substances work in concert with each other [20,21].

Based on that, several phytocomplexes have shown in vitro a promising activity against different cancer types $[18,22,23]$ and in oxidative and inflammatory states $[18,24,25]$. This evidence pushes research to better analyze and use this source for the research of compounds with remarkable biological activity and low toxic activity. Despite the promising biological activity exerted by the various phytocomplexes and their low toxicity towards healthy cells, a limit to their use is due to the possible reduced intestinal absorption and to the probable interactions with the intestinal microbiota [26]. Indeed, to overcame these problems, new carrier vehicles for their delivery are increasingly being studied [27].

Salvia rosmarinus Spenn. (Lamiaceae) is one of the most popular plants, commonly known as rosemary. The most used name, Rosmarinus officinalis, is considered a synonym of the actual name, Salvia rosmarinus, because several investigations evidenced as Rosmarinus L. are nested in Salvia L. [28]. S. rosmarinus is cultivated worldwide but it is native to the Mediterranean region. Rosemary leaves are extensively used traditionally to treat some diseases. In fact, this plant has drawn attention due to its biological activities, including antioxidant, antibacterial, hypoglycaemic, anticancer, hepatoprotective, anti-inflammatory, and antithrombotic effects [29-33]. These biological properties have made rosemary a new potential therapeutic agent for the treatment of many diseases. Furthermore, rosemary has been largely used in the Mediterranean diet and is widely used as a safe and effective natural antioxidant in the food industry. The biological properties of $S$. rosmarinus are principally attributed to the presence of polyphenols, including carnosic acid and rosmarinic acid, and phenolic diterpenes including carnosol $[34,35]$. While the chemical composition of these secondary metabolites varies considerably depending on ecological conditions, rosemary extracts contain biologically active compounds that make them unique [36].

The current study was planned to assess and to compare the chemical composition, the antioxidant power, the anti-inflammatory, and anti-cancer effects of four Italian $S$. rosmarinus extracts obtained by two extraction procedures and collected in two different localities of southern Italy, when the amount of carnosic acid was negligible. 


\section{Materials and Methods}

\subsection{Chemicals and Reagents}

Ascorbic acid, propyl gallate, 2,2-diphenyl-1-picrylhydrazyl (DPPH), butylated hydroxytoluene (BHT) $\beta$-carotene, and 2,2' -azino-bis(3-ethylbenzothiazoline-6-sulphonic acid) (ABTS), dimethyl sulfoxide (DMSO), and 3-(4,5-Dimethyl-2-thiazolyl)-2,5-diphenyl-2H-tetrazolium bromide (MTT) were acquired from Sigma-Aldrich S.p.a. (Milan, Italy). All solvents used in this study are of analytical grade. LC-MS quality grade acetonitrile and methanol were purchased from Carlo Erba (Val de Reuil, France). Ultrapure water (18.2 M $\Omega . c m)$ was obtained from Elga and Purelab Classic (Veolia Water, Antony, France). Formic acid (used at $10 \mathrm{~g} / \mathrm{L}$ ) was obtained from Carlo Erba (Val de Reuil, France). Standard compounds, luteolin-7-glucoside (purity $>98 \%$ ), rosmarinic acid (purity $>99 \%$ ), rutin (purity $>99 \%$ ), carnosol (purity $>90 \%$ ), carnosic acid (purity $>90 \%$ ), and ursolic acid (purity $>98 \%$ ) were purchased from Extrasynthese (Genay, France).

\subsection{Plant Materials}

The aerial parts of S. rosmarinus were harvested in May 2018 in two distinct sites of southern Italy, such as Praia a Mare (Tyrrhenian coast) (Latitude: 39 54' $6^{\prime \prime} 84 \mathrm{~N}$, Longitude: $15^{\circ} 46^{\prime} 48^{\prime \prime} 36 \mathrm{E}$; voucher specimen n. CLU 23974) and in June 2018 in Cirò superiore (Ionian coast) (Latitude $39^{\circ} 23^{\prime} 0^{\prime \prime} 24$ N, Longitude: $17^{\circ} 3^{\prime} 48^{\prime \prime} 24$ E; voucher specimen n. CLU 23969). Aerial parts of a single rosemary plant in each area were harvested in order to obtain an adequate quantity for the chemical and biological analyses and examined for integrity and absence of dust and insect contamination.

Samples were authenticated by Dr. NG Passalacqua at the Natural History Museum of Calabria and Botanic Garden, University of Calabria (Rende, CS, Italy).

\subsection{Extraction Procedure}

The fresh aerial parts of $S$. rosmarinus were exhaustively extracted by using methanol as a solvent by the following procedures: (a) maceration ( $250 \mathrm{~g}, 1 \mathrm{~L}, 3 \times 72 \mathrm{~h}$ ); (b) ultrasound-assisted extraction $(50 \mathrm{~g}, 150 \mathrm{~mL}, 3 \times 1 \mathrm{~h})$ using a Branson 3800 ultrasonic system, series CPXH (130 W, $40 \mathrm{kHz}$ frequency) (Milan, Italy). After being filtered (using Whatman N. 1 filter paper) and combined, extracted solutions were evaporated under reduced pressure in order to obtain dry crude extracts. Extracts were stored at $+4{ }^{\circ} \mathrm{C}$ in brown bottle until analyzed for their chemical profile and tested for their biological activity. Extracts of $S$. rosmarinus collected on the Ionian coast are indicated with the abbreviations R1 and R2 for maceration and ultrasound-assisted extraction, respectively. Extracts of S. rosmarinus collected on the Tyrrhenian coast are indicated with the abbreviations R3 and R4, for maceration and ultrasound-assisted extraction, respectively.

\subsection{HPLC-DAD-ESI-Q-MS Profiling}

Analyses of the four S. rosmarinus extracts were performed using an HPLC-DAD-MS ThermoScientific Dionex U3000 (Thermo-Dionex, Les Ulis, France) including a quaternary pump (LPG-3400 SD), an autosampler thermostat (WPS-3000TSL), a column thermostat (TCC-3000SD) and a Diode Array Detector (DAD-3000) (Thermo-Dionex, Les Ulis, France) on line with a quadripole mass spectrometer (Surveyor MSQ plus System, Thermo-Dionex, Les Ulis, France). The analytical column was a $100 \times 2.1 \mathrm{~mm}$ i.d. C18 Acclaim Polar advantage II ( $3 \mu \mathrm{m}, 120 \AA$ A), (Dionex Bonded Silica Products, Les Ulis, France) and it was heated to $35^{\circ} \mathrm{C}$ during the analyses. Before analyses, all extracts were filtered on $0.2 \mu \mathrm{m}$ Econo filter Nylon $13 \mathrm{~mm} 0.2 \mu \mathrm{m}$ (Agilent, Les Ulis, France). Two chromatographic mobile phases were employed for a gradient elution as follows: eluent-A formic acid $(1 \%, v / v)$ in water, eluent-B formic acid $(1 \%, v / v)$ in acetonitrile. The binary gradient was formulated as $5 \%$ eluent-B during 5 min then in 10 min eluent-B was reached 20\%, and in 5 min eluent-B was reached $25 \%$, in 10 min eluent-B was reached $30 \%$, in 10 min eluent-B was reached $40 \%$, in 5 min eluent-B was reached $50 \%$, in 5 min eluent-B was reached $80 \%$, then stay at $80 \%$ during 3 min before come back at 
initial conditions in $2 \mathrm{~min}$. The pump flow rate was $0.5 \mathrm{~mL} / \mathrm{min}$ and the injection volume was $20 \mu \mathrm{L}$. UV spectra were performed using a diode array detector with a wavelength scanning between 200 and $400 \mathrm{~nm}$.

Detection at specific wavelengths $210,254,280$, and $350 \mathrm{~nm}$, were used to record the chromatograms. The chromatographic effluent carried by a stream of nitrogen was directed into the electrospray ionization source [31] of the mass spectrometer (MS). The MS was operated in the positive and negative ionization modes with the following operating conditions: ion spray voltage $3 \mathrm{kV}$, curtain gas 50 psi, Q energy was $70 \mathrm{~V}$, cone voltage $50 \mathrm{~V}$, desolvatation temperature $500{ }^{\circ} \mathrm{C}$, and ion energy $0.8 \mathrm{~V}$. In all cases, mass spectra were acquired in the range of $100-1000 \mathrm{Th}$. Chromeleon ${ }^{\circledR}$, version 6.8 software provided by ThermoScientific Dionex (Les Ulis, France) was used for results' treatment. All experiments were conducted successively over 3 days, in triplicate each time. Finally, several compounds present in the extracts have been identified and quantified using a methanolic standard solution of compounds previously described in S. rosmarinus [37]. The following solutions have been prepared: luteolin-7-glucoside $(0.26 \mathrm{~g} / \mathrm{L})$, rosmarinic acid $(0.97 \mathrm{~g} / \mathrm{L})$, rutin $(0.16 \mathrm{~g} / \mathrm{L})$, carnosol $(0.51 \mathrm{~g} / \mathrm{L})$, carnosic acid $(0.50 \mathrm{~g} / \mathrm{L})$, and ursolic acid $(0.71 \mathrm{~g} / \mathrm{L})$. Calibration curves used a linear fitting (unweight and not forced to axis-origin) in the concentration range $0.008-0.4 \mathrm{~g} / \mathrm{L}$. A coefficient determination $R^{2}>0.99$ were used as acceptability thresholds for calibration purposes. Dry extracts of S. rosmarinus (R1-R4) are dissolved in methanol before being analyzed in HPLC-DAD-MS (R1, $2.04 \mathrm{~g} / \mathrm{L} ; \mathrm{R} 2,1.72 \mathrm{~g} / \mathrm{L} ; \mathrm{R} 3,1.84 \mathrm{~g} / \mathrm{L}$, and R4, $1.72 \mathrm{~g} / \mathrm{L})$. Chromatograms recorded of standards after HPLC-DAD-ESI-Q-MS experiments are reported in Supplementary Materials. All experiments were conducted successively over 3 days, in triplicate each time.

\subsection{In Vitro Antioxidant Activity}

Several approaches are used to investigate the antioxidant property of plant extracts. Antioxidant activity should not be investigated based on a single antioxidant assay. In fact, in practice various in vitro methods are carried out for evaluating the potential antioxidant effects with the samples of interest. Herein, four tests have been applied to analyze the antioxidant activity of rosemary extracts R1-R4.

\subsubsection{DPPH (2,2-diphenyl-1-picrylhydrazyl) Assay}

The DPPH radicals' scavenging activity of S. rosmarinus extracts was determined according to the method previously described [38]. A mixture of DPPH methanol solution $(800 \mu \mathrm{L}$ at concentrations of $\left.1.0 \times 10^{-4} \mathrm{M}\right)$, and methanol solutions of rosemary samples $(200 \mu \mathrm{L}$, at concentrations in the range $1-1000 \mu \mathrm{g} / \mathrm{mL}$ ) was prepared. The absorbance was read at $517 \mathrm{~nm}$.

\subsubsection{ABTS (2,2'-azino-bis(3-ethylbenzothiazoline-6-sulphonic acid)) Assay}

The ABTS radicals' scavenging assay measured the ability of an antioxidant to react with ABTS radicals [38]. As with the DPPH assay, the ABTS test is simple, rapid, and versatile with hydrophilic and lipophilic samples. S. rosmarinus extracts $(10 \mu \mathrm{L})$ (at concentrations in the range $1-400 \mu \mathrm{g} / \mathrm{mL}$ ) were added to the ABTS solution, and the absorbance was measured after $6 \mathrm{~min}$ at $734 \mathrm{~nm}$.

\subsubsection{Ferric Reducing Antioxidant Power (FRAP) Test}

The FRAP test measures the ability of antioxidants to reduce ferric iron. In particular, this method estimates the change in absorbance that occurs when the TPTZ (2,4,6-tripyridyl-s-triazine)-Fe ${ }^{3+}$ complex is reduced to the TPTZ-Fe ${ }^{2+}$ form in the presence of an antioxidant [39]. S. rosmarinus extracts were dissolved in methanol at the concentration of $2.5 \mathrm{mg} / \mathrm{mL}$ and tested. The absorbance was measured at $595 \mathrm{~nm}$. 


\subsubsection{Carotene Bleaching Test}

The ability of $S$. rosmarinus extracts to inhibit lipid peroxidation was examined by using the $\beta$-carotene bleaching test [39]. Rosemary extracts were tested at concentrations in the range of $1-100 \mathrm{\beta g} / \mathrm{mL}$ at initial time ( $\mathrm{t}=0 \mathrm{~min}$ ), and after 30 and $60 \mathrm{~min}$ of incubation, by using propyl gallate as a positive control.

\subsection{Cell Cultures}

Murine macrophages RAW 264.7 cell line were purchased from the American Culture Collection (ATCC, Manassas, VA, USA) and cultured in DMEM (Sigma, St. Louis, MO, USA) supplemented with 10\% Fetal Bovine Serum (FBS, Sigma-Aldrich), 2 mM L-glutamine (Gibco, Life Technologies, Waltham, MA, USA) and 1\% penicillin/streptomycin (Gibco, Life Technologies, Waltham, MA, USA). Breast cancer cells (MCF7 and MDA-MB-231) had been purchased from the American Culture Collection (ATCC) and cultured in DMEM/F12 (Sigma-Aldrich, St. Louis, MO, USA) supplemented with 10\% FBS, $2 \mathrm{mM}$ l-glutamine (Gibco, Life Technologies), and 1\% penicillin/streptomycin (Gibco, Life Technologies, Waltham, MA, USA). MCF-10A cells were cultured as previously reported [18]. All cell lines were cultured at $37{ }^{\circ} \mathrm{C}$ in $5 \% \mathrm{CO}_{2}$ in a humidified atmosphere [40]. Extracts were solubilized in DMSO and the solvent was kept at less than $1 \%$.

\subsection{Inhibition of NO Production in LPS-Stimulated RAW 264.7 Cells}

Griess reagent was used to determine the presence of nitrites, stable oxidized products of NO in cell culture media [25]. RAW 264.7 cells were seeded in 24 -well plates with a density of $2 \times 10^{5}$ cells $/$ well and cultured in complete medium overnight. Cells were then treated, simultaneously, with LPS $(1 \mu \mathrm{g} / \mathrm{mL})$ and different concentrations of extracts for $24 \mathrm{~h}$. DMSO (Sigma-Aldrich, St. Louis, MO, USA) was used as a vehicle control. Then, $100 \mu \mathrm{L}$ of cell culture supernatant was combined with $100 \mu \mathrm{L}$ of Griess reagent in a 96-well plate followed by spectrophotometric measurement at $550 \mathrm{~nm}$ using a microplate reader.

\subsection{Immuno-Fluorescence Monitoring Nuclear Factor Kappa B (NF-кB) Translocation}

RAW 264.7 cells were seeded on coverslip in 6-well plates at a density of $1 \times 10^{5}$ cells/well and cultured overnight in complete medium. Next, cells were treated for $1 \mathrm{~h}$ with LPS $(1 \mu \mathrm{g} / \mathrm{mL})$ and extracts, using their $\mathrm{IC}_{50}$ values. After treatment end, cells were fixed with ice cold methanol for $20 \mathrm{~min}$ at $-20^{\circ} \mathrm{C}$, washed three times for $5 \mathrm{~min}$ with Tris buffered saline (TBS, Sigma-Aldrich), and incubated for blocking with $5 \%$ bovine serum albumin (BSA, Sigma-Aldrich) in TBS for $40 \mathrm{~min}$ at $37^{\circ} \mathrm{C}$. Then, cells were incubated for $40 \mathrm{~min}$ at $37^{\circ} \mathrm{C}$ in anti-NF-KB p65 monoclonal antibody (Santa Cruz, Biotechnology, Dallas, TX, USA), diluted 1:200, as previously described [41]. Next, they were washed three times for $5 \mathrm{~min}$ with TBS to discard the excess of primary antibody, incubated for $40 \mathrm{~min}$ at $37^{\circ} \mathrm{C}$ in anti-mouse IgG-TRITC (Sigma-Aldrich) diluted 1:300, and subsequently washed three times for 5 min with TBS. Images at 20× magnification were taken on Olympus BX41 microscope with CSV1.14 software, using a CAMXC-30 for image acquisition.

\subsection{Reactive Oxygen Species Assessment}

$\mathrm{CM}-\mathrm{H}_{2}$ DCFDA (ThermoFisher Scientific, Waltham, MA, USA), is a fluorescent dye useful as an indicator for reactive oxygen species [9], as previously described [42,43]. Briefly, $2 \times 10^{5}$ RAW 264.7 cells/well were seeded in 6-well plates and treated with for $1 \mathrm{~h}$ with LPS $(1 \mu \mathrm{g} / \mathrm{mL})$ and extracts, using their $\mathrm{IC}_{50}$ values. After treatment, cells were washed with PBS, collected, resuspended in $5 \mu \mathrm{M}$ $\mathrm{CM}-\mathrm{H}_{2}$ DCFDA (ThermoFisher Scientific) in PBS, and incubated $45 \mathrm{~min}$ at $37^{\circ} \mathrm{C}$. Stained cells were collected by centrifugation, and resuspended in fresh pre-chilled medium. Finally, fluorescence of samples was quantified with a fluorimeter (Synergy H1 microplate reader, BioTek, Winooski, VT, USA), 
and fluorescence intensity was normalized by a viable cell number (TC20 automated cell counter, Bio-Rad, Hercules, CA, USA).

\subsection{Cell Viability Assay}

Cell viability was determined as described previously [44] by using 3-(4,5-Dimethyl-2-thiazolyl)2,5-diphenyl-2H-tetrazolium bromide (MTT, Sigma-Aldrich, St. Louis, MO, USA) assay. Briefly, RAW 264.7 cells have been treated with different concentrations of compounds for $24 \mathrm{~h}$. In the same way, MCF-7, MDA-MB-231 and MCF-10A cells have been treated with different concentrations of compounds for $72 \mathrm{~h}$. After treatment end, MTT solution was added to each well (to a final concentration of $0.5 \mathrm{mg} / \mathrm{mL}$ ) and plates were incubated at $37^{\circ} \mathrm{C}$ for $2 \mathrm{~h}$ until the formation of formazan crystals. DMSO-solubilized formazan in each well was quantified by reading the absorbance at $570 \mathrm{~nm}$ using a microplate reader.

\subsection{Wound-Healing Scratch Assay}

MCF-7 and MDA-MB-231 cells were seeded into 6-well plate and cultured overnight in complete medium to assess cell motility by wound-healing scratch assay [18]. Upon confluence, a wound was made by scratching across the monolayer cells on the bottom of the wells by using a p-200 pipette tip followed by treatment with extracts at $\mathrm{IC}_{50}$ values for $24 \mathrm{~h}$. Then, cells were fixed and stained with Coomassie brilliant Blue methanol solution.

Photographs were taken at $4 \times$ magnification using phase-contrast microscopy and are representative of three independent experiments. The rate of wound healing was quantified from the picture using Adobe Photoshop software and standard deviations were determined by GraphPad-Prism 8.3.0 software (GraphPad Inc., San Diego, CA, USA).

\subsection{Conditioned Medium Effects Assessment}

Production and collection of conditioned medium was conducted as previously described [45], with some modifications. MCF-7 and MDA-MB-231 cells were seeded into 24-well plate and cultured overnight in complete medium. Upon $70-80 \%$ of confluence, cells were treated with rosemary extracts at $\mathrm{IC}_{50}$ values, for $24 \mathrm{~h}$. Then, the medium was collected and dispensed into 24 -well plate, in which previously RAW 264.7 cells were plated, and incubated for $24 \mathrm{~h}$. Then, $100 \mu \mathrm{L}$ of cell culture supernatant was combined with $100 \mu \mathrm{L}$ of Griess reagent in a 96-well plate followed by spectrophotometric measurement at $550 \mathrm{~nm}$ using a microplate reader.

\subsection{TUNEL Assay}

Fragmentation of DNA, a late event during apoptosis, was determined by using terminal deoxynucleotidyl transferase-mediated deoxyuridine triphosphate nick end-labeling (TUNEL) assay, based on the enzymatic labelling of DNA strand breaks, using terminal deoxynucleotidyl transferase-mediated deoxyuridine triphosphate nick end-labeling (TUNEL) assay. Labeling was conducted using TUNEL assay kit (Promega, Madison, WI, USA), as previously described [46], on MCF-7 and MDA-MB-231 cells treated for $72 \mathrm{~h}$ with DMSO or extracts at $\mathrm{IC}_{50}$ values. Nuclear staining was performed by using $0.2 \mathrm{mg} / \mathrm{mL}$ 4',6- diamidino-2-phenylindole (DAPI; Sigma-Aldrich, St. Louis, MO, USA) and samples were analyzed by using a fluorescent microscope (Olympus BX4 (Shinjuku, Tokyo, Japan) with CSV1.14 software, using a CAMXC-30 for image acquisition).

\subsection{Hemolysis Assay}

Fresh human blood from healthy volunteers was collected in sodium citrate tubes and centrifuged at $2000 \mathrm{rpm}$ for $10 \mathrm{~min}$ to isolate red blood cells (RBCs) as a pellet, as previously described [47]. RBCs were washed three times with cold PBS pH 7.4 and resuspended in the same buffer $(10 \% v / v)$. Further, $60 \mu \mathrm{g} / \mathrm{mL}$ of the different extracts were added to the erythrocyte suspension and incubated for up to $24 \mathrm{~h}$ at $37^{\circ} \mathrm{C}$. The release of hemoglobin was determined after centrifugation (2000 rpm for 
$10 \mathrm{~min}$ ) by photometric analysis of the supernatant at $540 \mathrm{~nm}$ at two different endpoints (1 and $24 \mathrm{~h}$ ), using a microplate reader (Synergy H1 microplate reader, BioTek). Complete hemolysis was achieved by using $0.1 \%(v / v)$ Triton $\mathrm{X}-100$ which yielded the $100 \%$ positive control value while $0.5 \%$ DMSO, used as solvent for the extracts, gave the negative control value.

\subsection{Statistical Analysis}

Data are presented as the mean values \pm standard deviation, taken over $\geq 3$ independent experiments, with $\geq 3$ replicates per experiment, unless otherwise stated. Statistical significance was measured by using the analysis of variance (ANOVA) test. A $p$ value $\leq 0.05$ was considered statistically significant. Non-linear regression analysis (GraphPad Prism 8.3.0 software) was used to generate sigmoidal dose-response curves to calculate the $\mathrm{IC}_{50}$ values.

\section{Results and Discussion}

\subsection{Chemical Composition}

S. rosmarinus aerial parts collected in two different areas of southern Italy were herein subjected to two extraction procedures namely maceration and ultrasound-assisted extraction by using methanol as solvent. As evident in Table 1, except for R4, samples exhibited comparable extraction yields.

Table 1. Site of collection, extraction procedure, and extraction yield (\%) of S. rosmarinus samples.

\begin{tabular}{cccc}
\hline S. rosmarinus & $\begin{array}{c}\text { Site of Collection } \\
\text { (Southern Italy) }\end{array}$ & Extraction Procedure & Yield (\%) \\
\hline R1 & Cirò Superiore (Ionian coast) & Maceration & $11.63 \pm 1.34$ \\
R2 & & Ultrasound-assisted extraxction & $10.45 \pm 1.11$ \\
\hline R3 & Praia a Mare (Thyrrenian coast) & Maceration & $10.71 \pm 1.43$ \\
R4 & & Ultrasound-assisted extraxction & $7.44 \pm 0.87$ \\
\hline
\end{tabular}

Data are expressed as mean \pm S.D. $(n=3)$.

The phytochemical compositions of $S$. rosmarinus extracts were determined using an HPLC-DADESI-Q-MS mass spectrometric approach. The identification of rosmarinic acid, luteolin-7-glucoside, rutin, ursolic acid, carnosol, and carnosic acid was sought by authentic standards (Figure 1B). All compounds were identified based on UV spectra, molecular weight $\left(m / z\right.$ ion $[\mathrm{M}+\mathrm{H}]^{+}$and $\left.[\mathrm{M}-\mathrm{H}]^{-}\right)$, and bibliographic data concerning the phytochemical composition of $S$. rosmarinus previously published. Chromatograms allowed putative annotation of 18 compounds as reported in Figure 1A and in Table 2.

The results of the quantitative analysis are reported in Table 3 for the four Rosmarinus extracts. The commercial control, carnosic acid, and carnosol chromatograms showed several peaks (Figure 1B). These peaks were found in all extracts. The area of these peaks, varying over time, the dosage of these compounds was not carried out.

The results of the quantitative analysis are reported in Table 3 for the four Rosmarinus extracts. The commercial controls carnosic acid and carnosol chromatograms showed several peaks (Figure 1B). These peaks were found in all extracts. The area of these peaks varying over time, the dosage of these compounds was not carried out. Eighteen compounds were identified. Fifty-seven compounds have previously been inventoried from a commercial extract of the dried leaves of S. rosmarinus [37]. A review listed polyphenolic rosemary compounds [30]. Among them, thirteen phenolic acids have been mentioned, but only rosmarinic acid and caffeic acid are present in our extracts. Among the fifteen flavonoids listed in this publication, only a few flavonoids have been identified in the extracts R1-R4. 
(A)

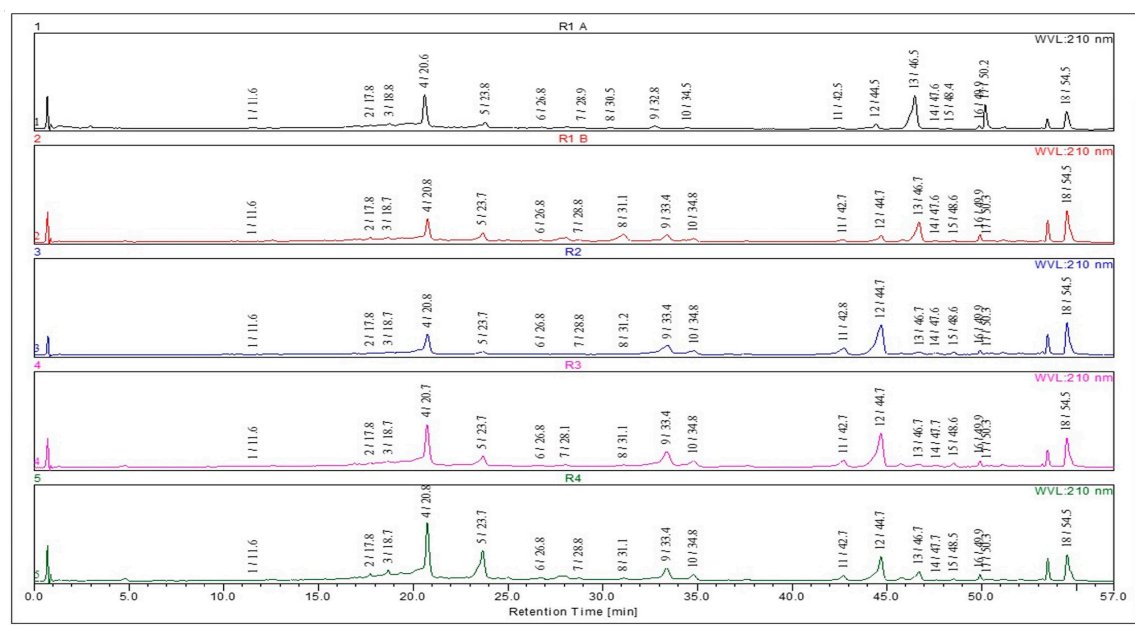

(B)

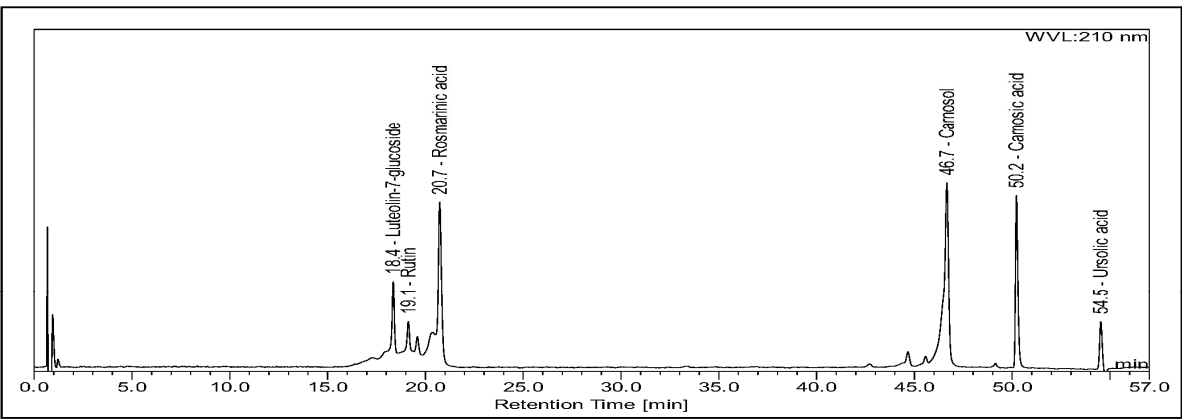

Figure 1. Compounds identification at $210 \mathrm{~nm}$ : (A) Profiles of $S$. rosmarinus extracts: $\mathrm{R} 1 \mathrm{~A} \mathrm{t}=1 \mathrm{~h}$, $\mathrm{R} 1 \mathrm{~B} \mathrm{t}=1 \mathrm{~d}, \mathrm{R} 2 \mathrm{t}=2 \mathrm{~d}, \mathrm{R} 3 \mathrm{t}=2 \mathrm{~d}$, and $\mathrm{R} 4 \mathrm{t}=2 \mathrm{~d}(\mathrm{t}=$ time between dissolution of the sample and analysis). (B) Mixture solution of standard compounds: luteolin-7-glucoside $(0.052 \mathrm{~g} / \mathrm{L})$, rosmarinic acid $(0.194 \mathrm{~g} / \mathrm{L})$, rutin $(0.032 \mathrm{~g} / \mathrm{L})$, carnosol $(0.102 \mathrm{~g} / \mathrm{L})$, carnosic acid $(0.082 \mathrm{~g} / \mathrm{L})$, and ursolic acid $(0.142 \mathrm{~g} / \mathrm{L})$.

Table 2. Retention time (Rt), wavelengths of maximum absorption in the UV-VIS region at $210 \mathrm{~nm}$, mass spectra data, and compounds identification in S. rosmarinus extracts.

\begin{tabular}{|c|c|c|c|c|c|c|}
\hline Peak & $\mathbf{R t}$ & $\begin{array}{c}\mathrm{UV} \\
\lambda(\mathrm{nm})\end{array}$ & $\begin{array}{l}\text { Molecular Ion } \\
{[\mathrm{M}-\mathrm{H}]^{-}(\mathrm{m} / \mathrm{z})}\end{array}$ & $\begin{array}{l}\text { Molecular Ion } \\
{[\mathrm{M}+\mathrm{H}]^{+}(\mathrm{m} / \mathrm{z})}\end{array}$ & Identification & Ref. \\
\hline 1 & 11.6 & $220 / 240 / 295 / 325$ & 179 & & Caffeic acid & {$[30]$} \\
\hline 2 & 17.8 & $200 / 225 / 285$ & 609 & 611 & Hesperidin & {$[30,37]$} \\
\hline 3 & 18.8 & $208 / 275 / 340$ & 477 & 479 & Isorhamnetin-3-O-hexoside & {$[30,37]$} \\
\hline 4 & 20.6 & $200 / 280 / 290 / 330$ & 359 & 361 & Rosmarinic acid (cis,trans) ${ }^{2}$ & {$[30]$} \\
\hline 5 & 23.8 & $205 / 242 / 270 / 340$ & 461 & 463 & Hispidulin-7-glucoside & {$[37]$} \\
\hline 6 & 26.8 & $205 / 270 / 340$ & 503 & 505 & $\begin{array}{l}\text { Luteolin- } \\
3^{\prime} \text {-acetyl-O-glucuronide }\end{array}$ & [37] \\
\hline 7 & 28.9 & $208 / 286$ & 345 & 347 & Rosmanol isomer ${ }^{1}$ & {$[30,37]$} \\
\hline 8 & 30.4 & $205 / 285$ & 345 & 347 & Rosmanol isomer ${ }^{1}$ & {$[30,37]$} \\
\hline 9 & 32.8 & $205 / 290$ & 345 & 347 & Rosmanol isomer ${ }^{1}$ & {$[30,37]$} \\
\hline 10 & 34.5 & $205 / 290$ & & 315 & Dihydroxydimethoxy flavone & [37] \\
\hline 11 & 42.5 & 208/280/335 & 283 & 285 & Genkwanin & {$[30,37]$} \\
\hline 12 & 44.4 & $207 / 291$ & 359 & & Rosmanol methylether isomer & [37] \\
\hline 13 & 46.5 & $205 / 286$ & 329 & 331 & Carnosol $^{2}$ & [30] \\
\hline 14 & 47.6 & $265 / 300 / 345$ & 593 & & Kaempferol & [30] \\
\hline 15 & 48.4 & $227 / 280$ & 315 & 317 & Rosmaridiphenol & [30] \\
\hline 16 & 49.9 & 208/233/285 & 345 & & 12-O-methylcarnosic acid & {$[30,37]$} \\
\hline 17 & 50.1 & $204 / 235 / 287$ & 331 & & Carnosic acid ${ }^{2}$ & {$[30,37]$} \\
\hline 18 & 54.5 & & & $593^{3}$ & Oleanolic acid/Ursolic acid ${ }^{2}$ & [30] \\
\hline
\end{tabular}


These are hesperidin, isorhamnetin-3-O-hexoside, genkwanin, and kaempferol. Studied extracts are rich in phenolic terpenes, in fact among the twelve previously described, eight of them were found in all of our extracts namely carnosic acid, 12-O-methylcarnosic acid, carnosol, three rosmanol isomers (epirosmanol, epiisorosmanol, and isorosmanol), rosmaridiphenol, and ursolic acid.

Table 3. Rosmarinic acid and triterpene acids quantification in dry extracts R1-R4 by HPLC-DAD-Q-MS.

\begin{tabular}{ccccc}
\hline Extract & \multicolumn{2}{c}{$\begin{array}{c}\text { Rosmarinic Acid } \\
\text { (Rt 20.6 min) }\end{array}$} & \multicolumn{2}{c}{$\begin{array}{c}\text { Triterpene Acids } \\
\text { (Rt 54.5 min) }\end{array}$} \\
\hline & $\left({ }^{*}\right)$ & $(\% \mathrm{~g} / \mathrm{g})$ & $\left.{ }^{*}\right)$ & $(\% \mathrm{~g} / \mathrm{g})$ \\
\hline $\mathrm{R} 1$ & $0.11 \pm 0.02$ & 5.39 & $0.340 \pm 0.008$ & 16.67 \\
$\mathrm{R} 2$ & $0.066 \pm 0.009$ & 3.84 & $0.380 \pm 0.023$ & 22.09 \\
$\mathrm{R} 3$ & $0.0384 \pm 0.0067$ & 2.09 & $0.393 \pm 0.043$ & 21.36 \\
R4 & $0.0407 \pm 0.0068$ & 2.37 & $0.167 \pm 0.026$ & 9.71
\end{tabular}

$(*)$ Results are expressed as means values $(\mathrm{g} / \mathrm{L})+$ standard deviation $(n=6)$. Rt: retention time.

The presence of dihydroxydimethoxy flavone, hispidulin-7-glucoside, luteolin-3'-acetyl-O-glucuronide and two rosmanolmethylether isomers have been confirmed by the work of Mena et al. [37].

Quantitative analyses of the R1-R4 extracts in triplicate over three days, showed similar profiles, and areas of invariable chromatographic peaks proving good stability of the main compounds. However, it should be noted that the concentration of carnosol and carnosic acid in the standard solutions as well as the solutions of all the extracts decreased during the analyses.

With regard to triterpenic acids, ursulic acid, and oleanolic acid, as they do not absorb in UV/Vis, their specific coefficients are similar and it can then be considered that aera under the chromatographic peak at Rt $54 \mathrm{mn}$ corresponds either to the sum of the injected amounts of these compounds. Thus, for the determination of the contents of triterpenic acids, the calibration line constructed with the ursulic acid alone can be used.

Analyzing results reported in Table 3, S. rosmarinus extracts from the Ionian side (R1 and R2) seem richer in rosmarinic acid (values of 3.84\% and 5.39\%, respectively) and in triterpene acids (values of $16.67 \%$ and $22.09 \%$ ) than the extracts from the Tyrrhenian side (R3 and R4) (values of 2.09\%, and 2.37\%, for rosmarinic acid, respectively, and $21.36 \%$ and $9.71 \%$ for triterpene acids, respectively).

\subsection{In Vitro Antioxidant Activity}

S. rosmarinus extracts were investigated in vitro for their potential antioxidant activity. Data are reported in Table 4. The analysis of results highlights that rosemary extracts from Ionian coast are more active than rosemary extracts from Tyrrhenian coast with some exception.

Table 4. In vitro antioxidant activity of S. rosmarinus extracts.

\begin{tabular}{|c|c|c|c|c|c|}
\hline \multirow[t]{2}{*}{ S. rosmarinus } & \multirow[t]{2}{*}{$\begin{array}{l}\text { DPPH a Test } \\
\mathrm{IC}_{50}(\mu \mathrm{g} / \mathrm{mL})\end{array}$} & \multirow[t]{2}{*}{$\begin{array}{l}\text { ABTS }{ }^{b} \text { Test } \\
\text { IC }_{50}(\mu \mathrm{g} / \mathrm{mL})\end{array}$} & \multicolumn{2}{|c|}{$\begin{array}{c}\beta \text {-carotene Bleaching Test } \\
\operatorname{IC}_{50}(\mu \mathrm{g} / \mathrm{mL})\end{array}$} & \multirow[t]{2}{*}{$\begin{array}{l}\text { FRAP }^{c} \text { Test } \\
\mu \mathrm{M} \mathrm{Fe}(\mathrm{II}) / \mathrm{g}^{1}\end{array}$} \\
\hline & & & $30 \mathrm{~min}$ & $60 \mathrm{~min}$ & \\
\hline R1 & $8.83 \pm 0.82 * *$ & $1.48 \pm 0.10$ & $12.53 \pm 1.20^{* * * *}$ & $8.87 \pm 0.85^{* * * *}$ & $95.17 \pm 6.62$ \\
\hline $\mathrm{R} 2$ & $8.80 \pm 0.81 * *$ & $0.94 \pm 0.09$ & $7.18 \pm 0.76^{* * * *}$ & $6.53 \pm 0.65^{* * * *}$ & $80.09 \pm 5.01$ \\
\hline $\mathrm{R} 3$ & $11.23 \pm 1.14^{* * * *}$ & $1.57 \pm 0.14^{* * *}$ & $45.57 \pm 3.90^{* * * *}$ & $26.61 \pm 2.62 * * * *$ & $97.20 \pm 6.30$ \\
\hline $\mathrm{R} 4$ & $14.76 \pm 1.42^{* * * *}$ & $2.01 \pm 0.24$ & $10.84 \pm 1.05^{* * * *}$ & $10.75 \pm 1.03^{* * * *}$ & $76.77 \pm 5.13$ \\
\hline \multicolumn{6}{|l|}{ Positive control } \\
\hline Ascorbic acid & $5.02 \pm 0.80$ & $1.71 \pm 0.06$ & & & \\
\hline $\begin{array}{c}\text { Propyl gallate } \\
\text { BHT }\end{array}$ & & & $0.09 \pm 0.004$ & $0.09 \pm 0.004$ & $63.20 \pm 4.32$ \\
\hline
\end{tabular}

Data are expressed as mean \pm S.D. $(n=3) .{ }^{1}$ : tested at concentration $2.5 \mathrm{mg} / \mathrm{mL}$. Differences within and between groups were evaluated by one-way analysis of variance test followed by a multicomparison Dunnett's test $\alpha=0.05$ compared with the positive controls ${ }^{* * * *} p<0.0001$, $^{* * *} p<0.001,{ }^{* *} p<0.01$. ${ }^{\text {a }}$ 2-diphenyl-1-picrylhydrazyl. b 2,2'-azino-bis(3-ethylbenzothiazoline-6-sulphonic acid. ${ }^{c}$ Ferric Reducing Antioxidant Power. 
In particular, the best radical scavenging power was observed with sample $\mathrm{R} 2$ with $\mathrm{IC}_{50}$ values of 0.94 and $8.80 \mu \mathrm{g} / \mathrm{mL}$ in an ABTS and DPPH test, respectively. Interesting results were obtained also in a $\beta$-carotene bleaching test with sample $\mathrm{R} 2$ with $\mathrm{IC}_{50}$ values of 7.18 and $6.53 \mu \mathrm{g} / \mathrm{mL}$ after 30 min and 60 min of incubation, respectively.

Conversely, sample R3 such as extract obtained by maceration of $S$. rosmarinus from Cirò superiore was the most active in FRAP test with a value of $97.20 \mu \mathrm{M} \mathrm{Fe}$ (II)/g.

\subsection{Nitric Oxide Production in RAW 264.7 Cells}

The relationship between oxidative stress and inflammation has been already reported [48], indeed various inflammatory stimuli, such as LPS, were able to initiate different chronic inflammatory diseases by modulating Nitric Oxide (NO) production [49]. NO is synthesized by the enzymatic activity of the inducible Nitric Oxide synthase ( $\mathrm{NOS}$ ) and is believed to be a key mediator of the inflammatory pathway in LPS-stimulated cells. Based on that, we next asked if our rosemary extracts could also act as anti-inflammatory agents. For this purpose, we investigated their ability to affect NO production by testing increasing concentrations of them, up to $60 \mu \mathrm{M}$ (from $10 \mu \mathrm{M}$ ), on LPS-stimulated RAW 264.7 cells, murine macrophages widely used as an in vitro model to study inflammatory pathways. Firstly, we assessed if the extracts could influence cell viability; the results displayed the different cytotoxicity behavior of them, related to their origin place. In particular, the extracts from samples collected on the Ionian coast (R1-R2) evidenced a slightly more cytotoxic effect compared to those of the R3-R4 extracts from the Tyrrhenian coast (Figure S1). Then, by using the four extracts, at non-toxic concentrations, we evaluated their inhibitory effect on NO production, and we found that all extracts are active, and particularly, R2 and R3 displayed the best activity (Figure S1 and Table 5).

Table 5. Nitrites production inhibitory activity ( $\mathrm{IC}_{50}$ values).

\begin{tabular}{cccc}
\hline \multicolumn{4}{c}{ IC $_{\mathbf{5 0}} \pm \mathrm{SD}(\boldsymbol{\mu g} / \mathrm{mL})$} \\
\hline $\mathbf{R 1}$ & $\mathbf{R 2}$ & $\mathbf{R 3}$ & $\mathbf{R 4}$ \\
\hline $3.46 \pm 0.78$ & $1.71 \pm 0.40$ & $2.03 \pm 0.20$ & $5.53 \pm 1.26$ \\
\hline
\end{tabular}

These findings are in agreement with literature data reporting similar anti-inflammatory properties of S. rosmarinus and its bioactive components, when tested in our same experimental model [50]. In addition, our results highlighted that diversity in terms of cytotoxicity and inhibitory effect on NO production, evidenced by different extracts, reflects their different origin. However, the similar behavior on NO production, evidenced for R2 and R3 extracts, belonging to plants from two different origin places and resulted by different extraction procedures, could be related to the same chemical composition of two extracts. Indeed, they are characterized by large amount of carnosic acid (CA) derivatives, widely known as anti-inflammatory agents.

\subsection{Rosemary Extracts Exert Anti-Inflammatory Effects by Reducing NF- $\kappa B$ Nuclear Translocation and Disrupting the MAPK/NF- $\mathrm{B}$ Pathway}

It is known that the inducible Nitric Oxide Synthase ( $i$ NOS) is an important target of the NF- $\kappa B$ transcription factor playing a critical role in inflammatory signal transduction [51,52]. Indeed, both the enzyme expression level and NO production are mediated by it $[49,53]$. In normal conditions, NF- $\mathrm{kB}$ is localized into the cytoplasm, while, in inflammatory responses, it is translocated into the nucleus where it binds to the promoter sequences of several pro-inflammatory genes, including $i$ NOS $[49,53]$. Considering the effects exerted by the rosemary extracts on NO production in LPS-stimulated RAW 264.7 cells, we tested their ability to reduce the NF- $\mathrm{KB}$ activation, by monitoring its translocation into the nucleus. The results obtained (Figure 2a) show that R3 and R4 extracts significantly inhibited nucleus translocation of the NF- $\mathrm{B}$, in respect to that assessed in LPS-stimulated RAW 264.7 cells. Conversely, R1 and R2 extracts were not able to act on the NF- $\mathrm{B}$ translocation suggesting that the 
reduction in NO production, previously observed, is due to a different mechanism that does not involve the NF- $\mathrm{BB}-$ mediated signaling pathway.

a
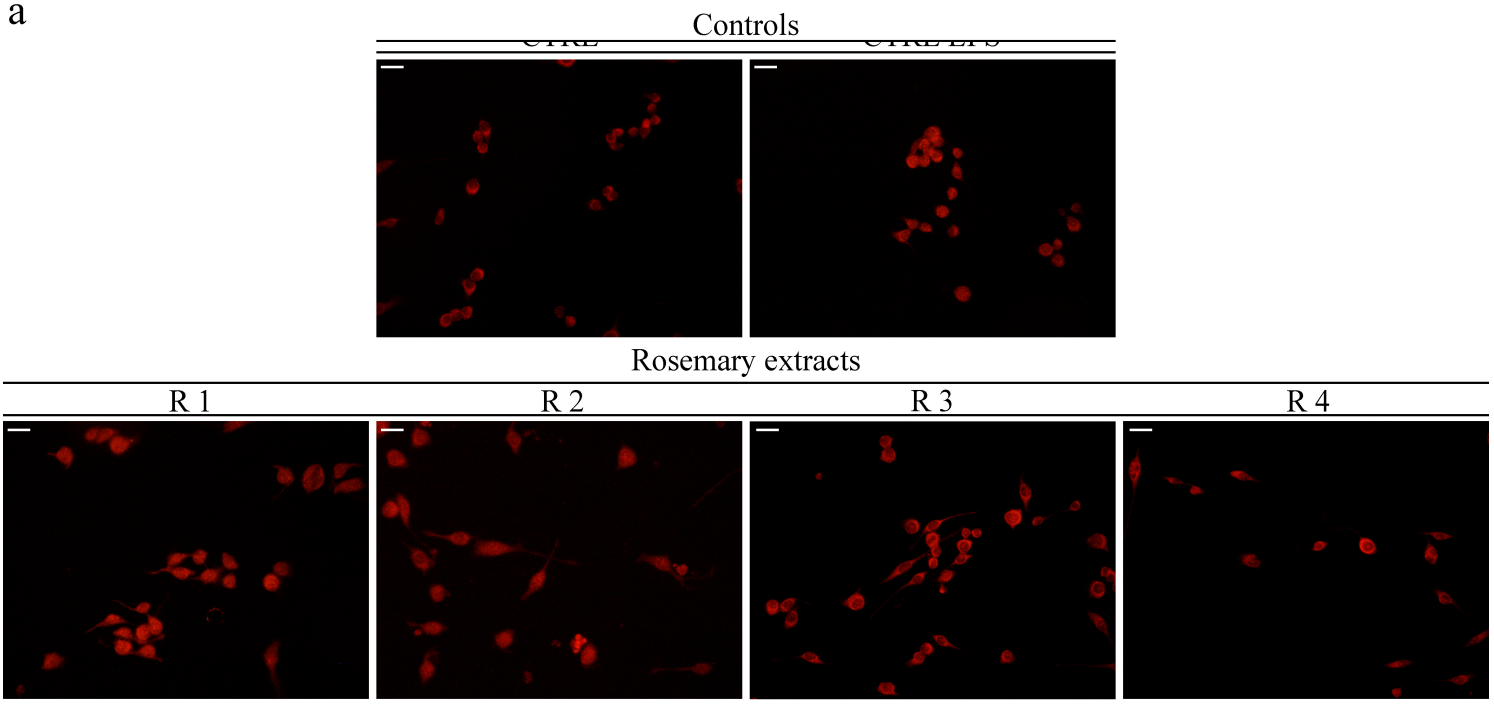

b
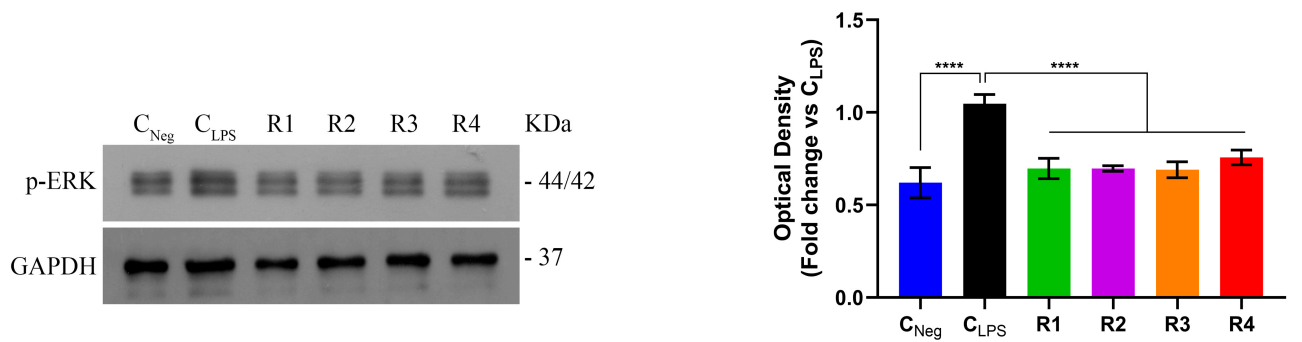

Figure 2. Effects of $S$. rosmarinus extracts on both NF- $\mathrm{BB}$ nuclear translocation and mitogen-activated protein kinases (MAPK)/NF- $\kappa B$ pathway. (a) Immuno-fluorescent localization of NF- $\kappa$ B in RAW 264.7 cells treated for $1 \mathrm{~h}$ with dimethyl sulfoxide (DMSO) or $1 \mu \mathrm{g} / \mathrm{mL}$ Lipopolysaccharide (LPS) + DMSO (Control (CTRL) and CTRL LPS, respectively), $1 \mu \mathrm{g} / \mathrm{mL}$ LPS + R1-R4 extracts (at their $\mathrm{IC}_{50}$ values, respectively). Scale bar: $50 \mu \mathrm{m}$. (b) Immunoblotting analysis of p-ERK and relative quantification of expression levels. Glyceraldehyde 3-phosphate dehydrogenase (GAPDH) was used as loading control. Values represent mean \pm S.D. of three independent experiments, each one performed with triplicate samples. $p$ values were calculated against $\mathrm{C}_{\mathrm{LPS}} ;{ }^{* * * *} p<0.001$.

It has been widely reported that, during the inflammatory process of LPS-stimulated macrophages, nuclear factor $-\kappa B(N F-\kappa B)$ activation, is related to that of mitogen-activated protein kinases (MAPKs) pathway [53]. MAPKs, together with NF-kB, trigger transcription of different inflammatory genes, modulating consequently the amplification and propagation of inflammatory-mediated stress signal [49].

The MAPKs pathway comprises several proteins, including extracellular signal-regulated kinase 1/2 (ERK1/2), p38, and c-Jun N-terminal kinase (JNK) [54]. Furthermore, it has been demonstrated that S. rosmarinus extracts can play beneficial effects on intestinal inflammation through NF-kB/MAPKs signaling pathway [55]. In this context, in order to investigate the molecular mechanisms that underly R1-R4 extracts' behavior, by Immunoblotting we assessed if they could play an inhibitory effect on LPS-induced phosphorylation of ERK1/2, the main intermediate proteins of the pathway. The results displayed that the phosphorylation levels of ERK1/2 were increased by LPS stimulation of RAW 264.7 macrophage cells, (Figure 2b). However, the treatment with R1-R4 extracts significantly decreased LPS-induced phosphorylation of ERK1/2 (Figure 2b). Our findings highlighted the R3 and R4 extracts' ability to significantly reduce the translocation of NF- $\mathrm{KB}$ into the nucleus, as well as the power of all the $S$. rosmarinus extracts tested to disrupt the MAPKs signal transduction pathway. 


\subsection{Rosemary Extracts Exerts Anti-Oxidant Effects by Reducing ROS Levels}

Since inflammation is closely related to oxidative stress and based on our previous findings that showed in vitro both anti-oxidant activity and an inhibitory effect on NO production of the rosemary extracts, we investigated if they could be able to regulate the reactive oxygen species [9] levels, in LPS-stimulated RAW 264.7 cells. In detail, LPS-stimulated RAW 264.7 cells were treated for $24 \mathrm{~h}$, with R1-R4 extracts, at IC 50 values. We proved that treatment significantly reduces ROS levels (Figure 3), accordingly to the results obtained in DPPH and ABTS assays and opening new scenarios for these extracts as radical scavengers.

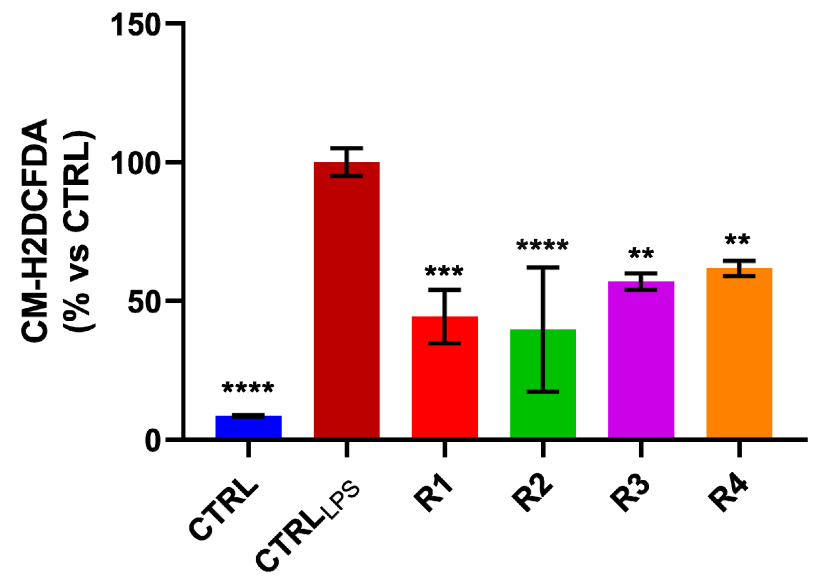

Figure 3. Rosemary extracts reduce Reactive Oxygen Species (ROS) levels in Lipopolysaccharide (LPS)-stimulated RAW 264.7 cells. ROS intracellular levels were measured after rosemary extracts (R1-R4) treatment of LPS-stimulated RAW 264.7 cells, for $24 \mathrm{~h}$. $p$ values were calculated against CTRL $_{\text {LPS }}{ }^{* *} p$ value $<0.01 ; * * *$ value $<0.001 ;{ }^{* * *} p$ value $<0.0001$

\subsection{Rosemary Extracts Showed a Promising Anti-Proliferative Effect on Breast Cancer Cell Lines}

Nowadays, the relationships among cellular oxidative stress, inflammation pathways, and cancer formation and propagation are well-known [50,56]. Moreover, having established that the treatment with rosemary extracts R1-R4 significantly disrupted the MAPKs pathway which is known to regulate cell events such as growth, differentiation, survival, and apoptosis [53], we then assessed the impact of the extracts on cancer cell viability. To this end two different breast cancer cell line, MCF-7 (ER $\alpha+)$ and MDA-MB-231 (triple negative) were plated for MTT assay in the presence of increasing concentrations $(10,20,40$, and $60 \mu \mathrm{g} / \mathrm{mL}$ ) of extracts or vehicle alone (Control), for $72 \mathrm{~h}$.

We found that all extracts concentration-dependently inhibited cell growth in both tested breast cancer cells (Figure S2), in particular in MDA-MB-231, with $\mathrm{IC}_{50}$ ranging from $6.83 \mu \mathrm{g} / \mathrm{mL}$ to $15.67 \mu \mathrm{g} / \mathrm{mL}$ (Table 6). These values are in agreement with the American National Cancer Institute criteria according to which the $\mathrm{IC}_{50}$ limit to consider a crude extract as promising anticancer agent should be lower than $30 \mu \mathrm{g} / \mathrm{mL}$ [57].

The anti-proliferative activity of rosemary extracts in MCF-7 cell lines was also interesting, showing an $\mathrm{IC}_{50}$ value ranging from 10.96 to $32.17 \mu \mathrm{g} / \mathrm{mL}$. Remarkably, anti-proliferative activities of extracts were found to be specific for cancer cells, indeed, their $\mathrm{IC}_{50}$ values in non-tumorigenic MCF-10A cell lines were higher rather than those found in all the tested cancer cell lines (Table 6 and Figure S2). Moreover, our findings are in complete agreement with literature data reporting anti-proliferative effects of different species of $S$. rosmarinus genus and highlighting the usefulness of this genus as a source of extracts with potential anticancer activity [58,59]. 
Table 6. Cytotoxic activity of S. rosmarinus extracts ${ }^{\text {a }}$.

\begin{tabular}{|c|c|c|c|c|c|}
\hline Cell Line & & R1 & R2 & R3 & R4 \\
\hline \multirow[b]{2}{*}{ MCF-7 } & $\mathrm{IC}_{50}(\mu \mathrm{g} / \mathrm{mL})$ & 11.48 & 10.96 & 23.33 & 32.17 \\
\hline & $\begin{array}{c}95 \% \text { confidence } \\
\text { interval }\end{array}$ & 8.688 to 14.90 & 8.391 to 14.06 & 17.07 to 31.77 & 27.43 to 37.72 \\
\hline \multirow[b]{2}{*}{ MDA-MB-231 } & $\mathrm{IC}_{50}(\mu \mathrm{g} / \mathrm{mL})$ & 8.648 & 6.830 & 12.24 & 15.67 \\
\hline & $\begin{array}{c}95 \% \text { confidence } \\
\text { interval }\end{array}$ & 5.687 to 12.50 & 4.169 to 10.31 & 7.992 to 17.94 & 12.80 to 19.09 \\
\hline \multirow[b]{2}{*}{ MCF-10A } & $\mathrm{IC}_{50}(\mu \mathrm{g} / \mathrm{mL})$ & 285.6 & 265.7 & 241.9 & 212.3 \\
\hline & $\begin{array}{l}95 \% \text { confidence } \\
\text { interval }\end{array}$ & 140.1 to 1456 & 137.4 to 987.8 & 140.1 to 585.9 & 93.64 to 1601 \\
\hline
\end{tabular}

${ }^{\mathrm{a}}$ Data are presented as $\mathrm{IC}_{50}$ values $(\mu \mathrm{g} / \mathrm{mL})$ and $95 \%$ confidence intervals obtained by nonlinear regression analysis of three independent experiments.

\subsection{Rosemary Extracts Trigger Cell Death by Apoptosis in Breast Cancer Cells}

Several reports demonstrated that rosemary extracts are able to trigger cell death by apoptosis in different human cancer cell lines. In particular, their polyphenolic compounds such as carnosic acid and carnosol induce apoptosis in PC3, DU-145, and LNCAP prostate cancer cells [60]. Similar results were evidenced on colon and pancreatic cancer cells; in this context, colon SW620 and DLD-1 cancer cells might be more sensitive, than PANC-1 and MIA-PaCa-2 pancreatic cancer cells, to the apoptotic effects of the rosemary extracts [61]. Interestingly, rosemary extract treatment induces apoptosis on the human ovarian cancer cell line A2780, as well as on the cisplatin resistant cell line A2780CP70, by modulating the expression levels of several genes involved in the pathway [62].

Taken together literature data prove that RE induce apoptosis in a wide range $(10-100 \mu \mathrm{g} / \mathrm{mL})$ of $\mathrm{IC}_{50}$ values, depending on the different extraction methods used to prepare the rosemary extract [58]. Particularly, a supercritical fluid rosemary extract dose-dependently induces apoptosis in breast cancer cells from different tumor subtypes including T47D and SK-BR-3 cell lines [63].

On this basis and considering the impact of rosemary extracts tested in this study on MCF-7 and MDA-MB-231 cell viability, we examined if the anti-proliferative activity displayed by them could be due to apoptosis induction. Since DNA fragmentation is a late event in the apoptotic cascade [64], we evaluated this process on both MCF-7 (Figure 4) or MDA-MB-231 (Figure S3) cells after $72 \mathrm{~h}$ of R1-R4 extracts exposure, by TUNEL assay. The results revealed that the percentage of TUNEL-positive cells significantly increased in both cell lines, with respect to control (DMSO-treated) cells. 

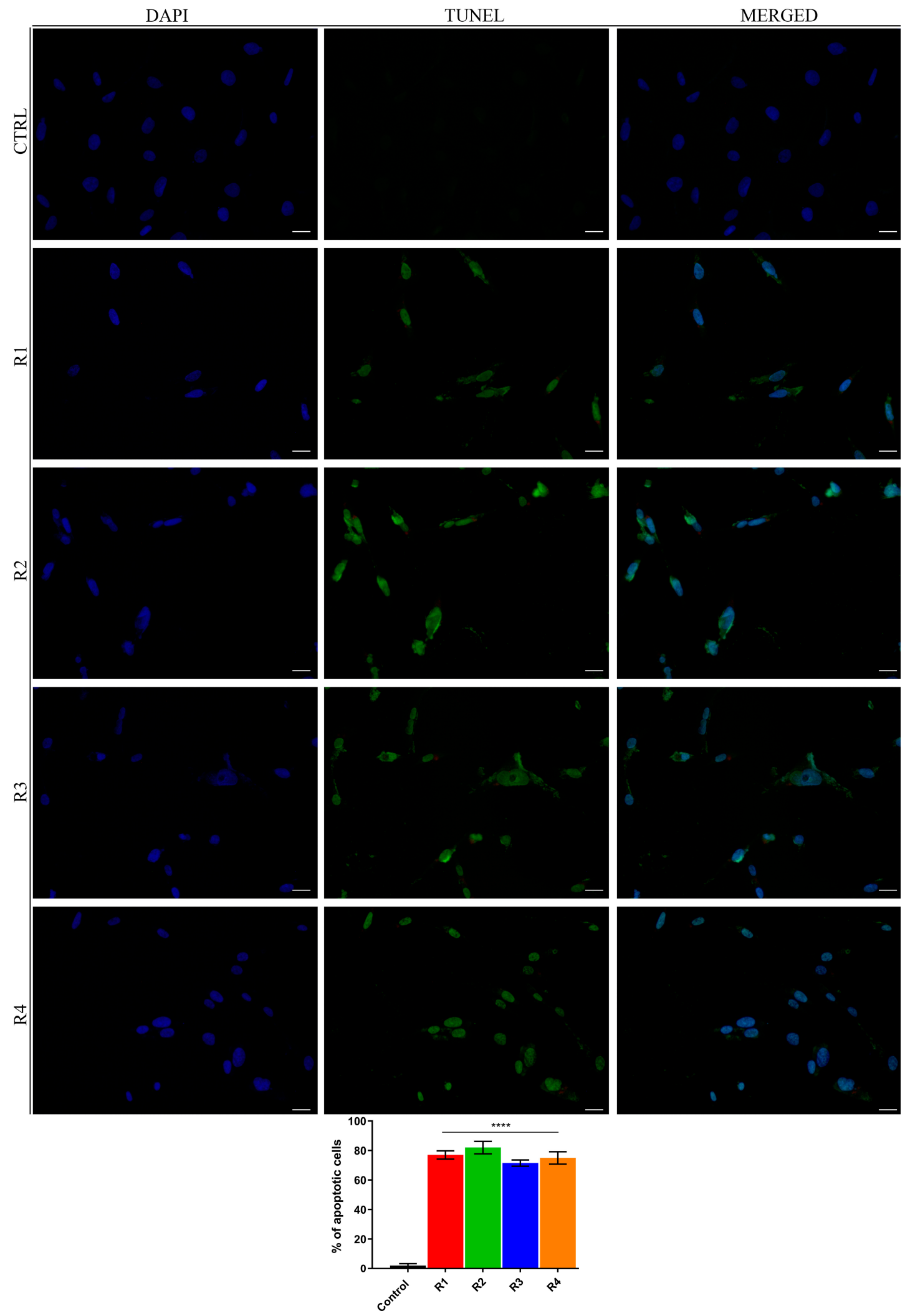

Figure 4. S. rosmarinus extracts induce cell apoptotic death. TdT-mediated dUTP nick-end-labeling (TUNEL) assay in MCF-7 cells treated for $72 \mathrm{~h}$ with vehicle (Control) or rosemary extracts (R1-R4). The 4',6- diamidino-2-phenylindole (DAPI) was used for DNA staining, scale bar: $50 \mu \mathrm{m}$. Histograms represent means \pm S.D. of apoptotic vs control cells from three independent experiments performed in triplicate. $p$ values were calculated against control; ${ }^{* * * *} p$ value $<0.0001$ 


\subsection{Rosemary Reduces MDA-MB-231 Cells Motility and Pro-Inflammatory Behavior of Breast Cancer Cells}

Based on the anti-proliferative activity showed by rosemary extracts in the highly invasive and metastatic MDA-MB-231, we next asked if they are also able to exert anti-migratory effects. Cell migration is a very unfavorable feature, because it triggers cancer dissemination and initiates metastatic events [65]. The effect of each extract on motility was performed evaluating the ability of the MDA-MB-231 cells to invade the wound area by wound healing scratch assay. The results showed that, after $24 \mathrm{~h}$ of rosemary extracts (R1-R4) exposure, the percentage of wound closure of these cells was significantly reduced when compared to that of the vehicle-treated cells (DMSO) used as a control (Figure 5a). This evidence underlines the potential ability of the tested extracts to decrease the cell motility, and thus could counteract the metastatic capability of this cancer cell line, which still remains the main cause for therapy failure.

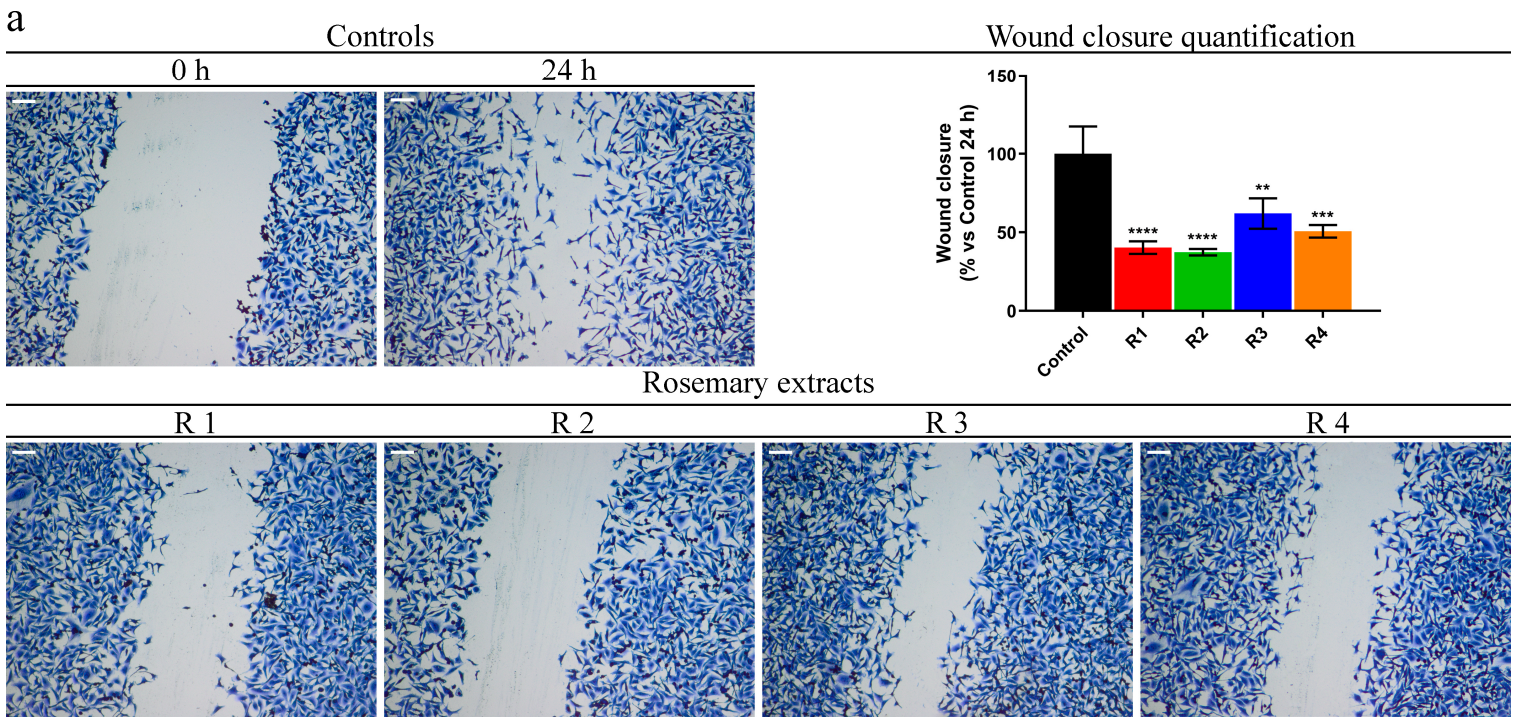

b

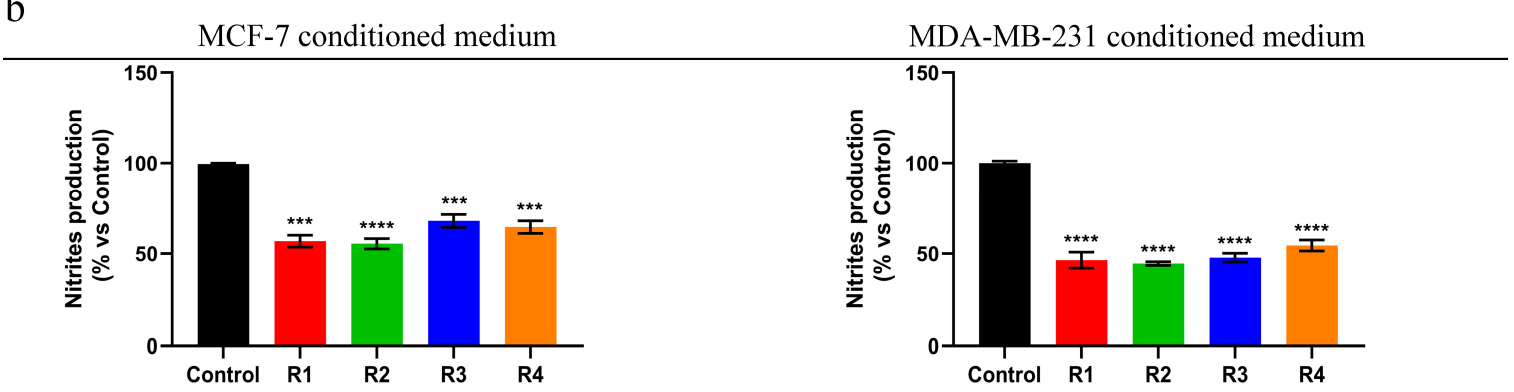

Figure 5. Rosemary extracts (R1-R4) reduce MDA-MB-231 cell motility and pro-inflammatory effects of MCF-7 and MDA-MB-231 conditioned medium. (a) Scratch assay on MDA-MB-231 cells treated with dimethyl sulfoxide (DMSO; Control), rosemary extracts (as indicated) at $\mathrm{IC}_{50}$ value. Scale bars $50 \mu \mathrm{m}$. Histograms represent the relative percentage of wound closure from three different experiments, each performed with triplicate samples. (b) Nitrites production assessments after treatment of RAW 264.7 cell line with conditioned medium of MCF-7 or MDA-MB-231 (previously treated with IC $_{50}$ values of rosemary extracts for $24 \mathrm{~h}$ ) for $24 \mathrm{~h} . \quad p$ value were calculated against Control; ${ }^{* *} p$ value $<0.01$; ${ }^{* * *} p$ value $<0.001 ;{ }^{* * * *} p$ value $<0.0001$

During the last decades, different studies established an interesting correlation between inflammation and cancer progression; many cancers are characterized by an etiopathogenesis linked to chronic inflammatory processes [14]. Moreover, tumor cells during their growth release, in the tumor microenvironment, pro-inflammatory mediators which attract leukocytes and modulate the behavior of tumor cells. In the solid tumor microenvironment the inflammatory component may 
involve different leukocyte population; however, macrophages are the most abundant inflammatory cells, which can enhance the invasiveness of breast cancer [66,67]. In this context, the effect of each rosemary extract on the pro-inflammatory behavior of breast cancer cells was evaluated. In particular, by Griess assay, we monitored the ability of conditioned media (CM), from MCF-7 or MDA-MB-231 cells, exposed for $24 \mathrm{~h}$ to R1-R4 extracts, to determine NO production on RAW 264.7 cells. The results showed that the treatment significantly reduces the ability of CM to induce NO production on RAW 264.7 cells, with respect to that of CM from control cells (DMSO-treated cells) (Figure 5b).

\subsection{Rosemary Extracts Did Not Exert Hemolytic Effects on Peripheral Blood}

Finally, in order to evaluate the translational potential of the studied rosemary extracts (R1-R4), we assessed their behavior in human blood by a hemolysis test. This test is commonly used in toxicity studies of interesting plant extracts in the medical field [47].

Due to that, the test was performed by using peripheral blood from healthy volunteer. The results, shown in Figure S4, highlighted the non-hemolytic feature of all the extracts, with acceptable hemolysis rate up to the maximum concentration tested $(60 \mu \mathrm{g} / \mathrm{mL})$.

\section{Conclusions}

Bioactive compounds isolated from natural products play a dominant role as potential drugs with utility in many diseases [59]. Herein we evaluated and compared the biological effects of four extracts of S. rosmarinus (R1-R4) collected in two distinct sites of Southern Italy. The extraction was performed by two different procedures, the maceration (extracts R1 and R3) and ultrasound-assisted extraction (extracts R2 and R4). For a long time, S. rosmarinus has been used in traditional medicine for attending to several diseases. Recently, literature data established that its extracts are endowed with antioxidant, anti-inflammatory, and anticancer properties [68].

Our findings evidenced that the four extracts tested are provided with antioxidant properties, although rosemary extracts from Ionian coast are more active than those from Tyrrhenian coast.

Additionally, we found that R1-R4 extracts treatment significantly reduced ROS levels, in LPS-stimulated RAW 264.7 cells, according to their antioxidant activity and proposing these extracts as radical-scavenger candidates. Based on literature data indicating that antioxidant properties are related to anti-inflammatory behavior [48], we established that all extracts are also endowed with anti-inflammatory activity as evidenced by a decrease in NO production. However, only R3-R4 extracts exert this effect involving the NF- $\mathrm{kB}$-mediated signaling pathway.

In the same way, the different behavior of the extracts concerning inhibitory effect on NO production is sometimes related to their different origin, rather than different extraction procedure used. This result prompt us to assert that ultrasound-assisted extraction is a very quick process, alternative to the maceration procedure, able to produce cleaner bioactive $S$. rosmarinus leaf extracts. Furthermore, according to the ability of S. rosmarinus extracts to disrupt the MAPKs signal transduction pathway, which is known to regulate cell events such as growth, differentiation, survival, and apoptosis [39], we demonstrated that $S$. rosmarinus R1-R4, although poor in carnosic acid, are able to exert anti-proliferative activity in MCF-7 and MDA-MB-231 breast cancer cells and to trigger cell death by apoptosis.

Interestingly, we found that the studied extracts can reduce both pro-inflammatory behavior and motility of MDA-MB-231 cells, a highly invasive breast cancer cell line, evidencing their potential ability to counteract the metastatic ability of this cancer cell line, which yet remains the main cause for therapy failing. Noteworthy, our findings evidenced a lack of toxic effects on red blood cells, thus supporting a safe use of the extracts in in vivo experimental models. However, the several biological activities (such as antioxidant and cytotoxic activities) exerted by rosemary extracts and clearly explained in this report highlight the $S$. rosmarinus as an interesting source of biologically active compounds. At the same time, more studies are needed to better understand their intestinal absorption. In this context, numerous studies have been developed [69-71], although most of them have been focused on carnosic 
acid, which is contemplate the most bioactive compound in rosemary extracts [72,73]. Recent evidence highlighted that polyphenols in a rosemary infusion were partly absorbed and widely metabolized in both HepG2 and Caco-2 cells, as in vitro models of liver and intestine, respectively [74]. Additionally, it will be needful to investigate on the intestinal microbiota activity which could limit phytocomplexes' effects. Indeed, some reports demonstrated that human microbiota are able to meddle with both bioavailability and bioactivity of phytocomplexes.

Phytocomplexes can be metabolized by the microbiota, but they can also modulate it, in order to improve their role in the prevention and amelioration of several diseases [75]. Moreover, the presence of several classes of compounds identified in all the extracts tested underlines the need to further analyze the effects of their single bioactive components.

Supplementary Materials: The following are available online at http://www.mdpi.com/2076-3921/9/9/826/s1, Figure S1: S. rosmarinus extracts (R1-R4) modulate nitric oxide (NO) production. Cell viability and nitrites production assessments after treatment of LPS-stimulated RAW 264.7 cell line with different concentration of extracts (as indicated) for $24 \mathrm{~h}$. MTT assay results are expressed as percentage of cell viability versus Control; Griess assay results are expressed as percentage of nitrites production versus Control. Values represent mean \pm S.D. of three independent experiments, each one performed with triplicate samples. $p$ value were calculated against Control; ${ }^{* * *} p<0.005 ;{ }^{* * * *} p<0.001$. Figure S2: Effect of rosemary extracts (R1-R4) treatment on cell viability. Cell growth assessment after treatment for $72 \mathrm{~h}$ of MCF-7, MDA-MB-231 and MCF-10A cell lines, using different concentrations (from 10 to $60 \mu \mathrm{g} / \mathrm{mL}$ ) of R1-R4, as indicated. Results were quantified by MTT assay and expressed as percentage of growth vs control (cells treated with DMSO, Control). Values represent means \pm S.D. of three independent experiments, each performed with triplicate samples. $p$ value were calculated against Control; ${ }^{*} p$ value $<0.05 ; * * * *$ value $<0.0001$. Figure S3: S. rosmarinus extracts induce cell apoptotic death. TdT-mediated dUTP nick-end-labeling (TUNEL) assay in MDA-MB-231 cells treated for $72 \mathrm{~h}$ with vehicle (Control) or rosemary extracts (R1-R4). DAPI was used for DNA staining, scale bar: $50 \mu \mathrm{m}$. Histograms represent means \pm S.D. of apoptotic vs control cells from three independent experiments performed in triplicate. $p$ value were calculated against Control; ${ }^{* * * *} p$ value $<0.0001$. Figure S4: Rosemary extracts did not exert haemolytic effects. Haemolysis assay on RBCs treated with DMSO (Control), $0.1 \%$ Tween-100 or rosemary extracts (R1-R4), for $1 \mathrm{~h}$ or $24 \mathrm{~h}$. Histograms represent the relative percentage of hemolysis from three different experiments, each performed with triplicate samples. $p$ value were calculated against $0.1 \%$ Tween- 100 ; **** $p$ value $<0.0001$. Figure S5. Standard compounds: luteolin-7-glucoside $(0.26 \mathrm{~g} / \mathrm{L})$, rosmarinic acid $(0.97 \mathrm{~g} / \mathrm{L})$, rutin $(0.16 \mathrm{~g} / \mathrm{L})$, carnosol $(0.51 \mathrm{~g} / \mathrm{L})$, carnosic acid $(0.50 \mathrm{~g} / \mathrm{L})$, and ursolic acid $(0.71 \mathrm{~g} / \mathrm{L})$. Figure S6. Standard compounds spectra. Figure S7. Sample compounds spectra.

Author Contributions: Conceptualization, R.T. and A.R.C.; chemical analysis, C.B., A.D. and B.D.; biological investigation, M.B., L.F., M.S.C. and M.R.L.; writing-original draft preparation, M.B., L.F., A.R.C., R.T., and B.D.; writing-review and editing, R.T., M.R.L., and M.S.C.; supervision, R.T. and M.S.C. All authors have read and agreed to the published version of the manuscript.

Funding: This research received no external funding.

Acknowledgments: Authors thank N.G. Passalacqua of the Botany Department at the University of Calabria (Italy) for samples identification.

Conflicts of Interest: The authors declare that there is no conflict of interest.

\section{References}

1. Jemal, A.; Bray, F.; Center, M.M.; Ferlay, J.; Ward, E.; Forman, D. Global cancer statistics. CA Cancer J. Clin. 2011, 61, 69-90. [CrossRef] [PubMed]

2. Takahashi, H.; Aoyagi, K.; Nakanishi, Y.; Sasaki, H.; Yoshida, T.; Honda, H. Classification of intramural metastases and lymph node metastases of esophageal cancer from gene expression based on boosting and projective adaptive resonance theory. J. Biosci. Bioeng. 2006, 102, 46-52. [CrossRef] [PubMed]

3. Chang, C.C.; Chen, W.C.; Ho, T.F.; Wu, H.S.; Wei, Y.H. Development of natural anti-tumor drugs by microorganisms. J. Biosci. Bioeng. 2011, 111, 501-511. [CrossRef]

4. Hussain, S.P.; Hofseth, L.J.; Harris, C.C. Radical causes of cancer. Nat. Rev. Cancer 2003, 3, 276-285. [CrossRef] [PubMed]

5. Danaei, G.; Vander Hoorn, S.; Lopez, A.D.; Murray, C.J.; Ezzati, M. Comparative risk assessment collaborating, g. Causes of cancer in the world: Comparative risk assessment of nine behavioural and environmental risk factors. Lancet 2005, 366, 1784-1793. [CrossRef] 
6. Grivennikov, S.I.; Greten, F.R.; Karin, M. Immunity, inflammation, and cancer. Cell 2010, 140, $883-899$. [CrossRef]

7. Valko, M.; Rhodes, C.J.; Moncol, J.; Izakovic, M.; Mazur, M. Free radicals, metals and antioxidants in oxidative stress-induced cancer. Chem. Biol. Interact. 2006, 160, 1-40. [CrossRef]

8. Benz, C.C.; Yau, C. Ageing, oxidative stress and cancer: Paradigms in parallax. Nat. Rev. Cancer 2008, 8, 875-879. [CrossRef]

9. Clendening, J.W.; Pandyra, A.; Boutros, P.C.; El Ghamrasni, S.; Khosravi, F.; Trentin, G.A.; Martirosyan, A.; Hakem, A.; Hakem, R.; Jurisica, I.; et al. Dysregulation of the mevalonate pathway promotes transformation. Proc. Natl. Acad. Sci. USA 2010, 107, 15051-15056. [CrossRef]

10. Sabharwal, S.S.; Schumacker, P.T. Mitochondrial ROS in cancer: Initiators, amplifiers or an Achilles' heel? Nat. Rev. Cancer 2014, 14, 709-721. [CrossRef]

11. Cairns, R.A.; Harris, I.S.; Mak, T.W. Regulation of cancer cell metabolism. Nat. Rev. Cancer 2011, 11, 85-95. [CrossRef] [PubMed]

12. Lichtenstern, C.R.; Ngu, R.K.; Shalapour, S.; Karin, M. Immunotherapy, Inflammation and Colorectal Cancer. Cells 2020, 9, 618. [CrossRef] [PubMed]

13. Pikarsky, E.; Porat, R.M.; Stein, I.; Abramovitch, R.; Amit, S.; Kasem, S.; Gutkovich-Pyest, E.; Urieli-Shoval, S.; Galun, E.; Ben-Neriah, Y. NF-kappaB functions as a tumour promoter in inflammation-associated cancer. Nature 2004, 431, 461-466. [CrossRef] [PubMed]

14. Coussens, L.M.; Werb, Z. Inflammation and cancer. Nature 2002, 420, 860-867. [CrossRef]

15. Farrow, B.; Sugiyama, Y.; Chen, A.; Uffort, E.; Nealon, W.; Mark Evers, B. Inflammatory mechanisms contributing to pancreatic cancer development. Ann. Surg. 2004, 239, 763-771. [CrossRef]

16. Atreya, R.; Neurath, M.F. Involvement of IL-6 in the pathogenesis of inflammatory bowel disease and colon cancer. Clin. Rev. Allergy Immunol. 2005, 28, 187-196. [CrossRef]

17. Soria, G.; Ben-Baruch, A. The inflammatory chemokines CCL2 and CCL5 in breast cancer. Cancer Lett. 2008, 267, 271-285. [CrossRef]

18. Bonesi, M.; Brindisi, M.; Armentano, B.; Curcio, R.; Sicari, V.; Loizzo, M.R.; Cappello, M.S.; Bedini, G.; Peruzzi, L.; Tundis, R. Exploring the anti-proliferative, pro-apoptotic, and antioxidant properties of Santolina corsica Jord. \& Fourr. (Asteraceae). Biomed. Pharmacother. 2018, 107, 967-978. [CrossRef]

19. da Rocha, A.B.; Lopes, R.M.; Schwartsmann, G. Natural products in anticancer therapy. Curr. Opin. Pharmacol. 2001, 1, 364-369. [CrossRef]

20. Cragg, G.M.; Grothaus, P.G.; Newman, D.J. Impact of natural products on developing new anti-cancer agents. Chem. Rev. 2009, 109, 3012-3043. [CrossRef]

21. Zu, Y.; Yu, H.; Liang, L.; Fu, Y.; Efferth, T.; Liu, X.; Wu, N. Activities of ten essential oils towards Propionibacterium acnes and PC-3, A-549 and MCF-7 cancer cells. Molecules 2010, 15, 3200-3210. [CrossRef] [PubMed]

22. Celia, C.; Trapasso, E.; Locatelli, M.; Navarra, M.; Ventura, C.A.; Wolfram, J.; Carafa, M.; Morittu, V.M.; Britti, D.; Di Marzio, L.; et al. Anticancer activity of liposomal bergamot essential oil (BEO) on human neuroblastoma cells. Colloids Surf. B Biointerfaces 2013, 112, 548-553. [CrossRef] [PubMed]

23. Fiorillo, M.; Peiris-Pages, M.; Sanchez-Alvarez, R.; Bartella, L.; Di Donna, L.; Dolce, V.; Sindona, G.; Sotgia, F.; Cappello, A.R.; Lisanti, M.P. Bergamot natural products eradicate cancer stem cells (CSCs) by targeting mevalonate, Rho-GDI-signalling and mitochondrial metabolism. Biochim. Biophys. Acta Bioenerg. 2018, 1859, 984-996. [CrossRef] [PubMed]

24. Siracusa, L.; Saija, A.; Cristani, M.; Cimino, F.; D’Arrigo, M.; Trombetta, D.; Rao, F.; Ruberto, G. Phytocomplexes from liquorice (Glycyrrhiza glabra L.) leaves-chemical characterization and evaluation of their antioxidant, anti-genotoxic and anti-inflammatory activity. Fitoterapia 2011, 82, 546-556. [CrossRef]

25. Frattaruolo, L.; Carullo, G.; Brindisi, M.; Mazzotta, S.; Bellissimo, L.; Rago, V.; Curcio, R.; Dolce, V.; Aiello, F.; Cappello, A.R. Antioxidant and anti-inflammatory activities of flavanones from Glycyrrhiza glabra L. (licorice) leaf phytocomplexes: Identification of licoflavanone as a modulator of NF-kB/MAPK Pathway. Antioxidants 2019, 8, 186. [CrossRef]

26. Dabulici, C.M.; Sarbu, I.; Vamanu, E. The bioactive potential of functional products and bioavailability of phenolic compounds. Foods 2020, 9, 953. [CrossRef] 
27. Vulic, J.; Seregelj, V.; Kalusevic, A.; Levic, S.; Nedovic, V.; Tumbas Saponjac, V.; Canadanovic-Brunet, J.; Cetkovic, G. Bioavailability and bioactivity of encapsulated phenolics and carotenoids isolated from red pepper waste. Molecules 2019, 24, 2837. [CrossRef]

28. Drew, B.T.; González-Gallegos, J.G.; Xiang, C.L.; Kriebel, R.; Drummond, C.P.; Walker, J.B.; Sytsma, K.J. Salvia united: The greatest good for the greatest number. Taxon 2017, 66, 133-145. [CrossRef]

29. Bozin, B.; Mimica-Dukic, N.; Samojlik, I.; Jovin, E. Antimicrobial and antioxidant properties of rosemary and sage (Rosmarinus officinalis L. and Salvia officinalis L., Lamiaceae) essential oils. J. Agric. Food Chem. 2007, 55, 7879-7885. [CrossRef]

30. Naimi, M.; Vlavcheski, F.; Shamshoum, H.; Tsiani, E. Rosemary extract as a potential anti-hyperglycemic agent: Current evidence and future perspectives. Nutrients 2017, 9, 968. [CrossRef]

31. Cheung, S.; Tai, J. Anti-proliferative and antioxidant properties of rosemary Rosmarinus officinalis. Oncol. Rep. 2007, 17, 1525-1531. [CrossRef] [PubMed]

32. Perez-Fons, L.; Garzon, M.T.; Micol, V. Relationship between the antioxidant capacity and effect of rosemary (Rosmarinus officinalis L.) polyphenols on membrane phospholipid order. J. Agric. Food Chem. 2010, 58, 161-171. [CrossRef] [PubMed]

33. Yamamoto, J.; Yamada, K.; Naemura, A.; Yamashita, T.; Arai, R. Testing various herbs for antithrombotic effect. Nutrition 2005, 21, 580-587. [CrossRef] [PubMed]

34. Yesil-Celiktas, O.; Sevimli, C.; Bedir, E.; Vardar-Sukan, F. Inhibitory effects of rosemary extracts, carnosic acid and rosmarinic acid on the growth of various human cancer cell lines. Plant Foods Hum. Nutr. 2010, 65, 158-163. [CrossRef] [PubMed]

35. Erkan, N.; Ayranci, G.; Ayranci, E. Antioxidant activities of rosemary (Rosmarinus officinalis L.) extract, blackseed (Nigella sativa L.) essential oil, carnosic acid, rosmarinic acid and sesamol. Food Chem. 2008, 110, 76-82. [CrossRef] [PubMed]

36. Peng, Y.; Yuan, J.; Liu, F.; Ye, J. Determination of active components in rosemary by capillary electrophoresis with electrochemical detection. J. Pharm. Biomed. Anal. 2005, 39, 431-437. [CrossRef] [PubMed]

37. Mena, P.; Cirlini, M.; Tassotti, M.; Herrlinger, K.A.; Dall'Asta, C.; Del Rio, D. Phytochemical profiling of flavonoids, phenolic acids, terpenoids, and volatile fraction of a rosemary (Rosmarinus officinalis L.) Extract. Molecules 2016, 21, 1576. [CrossRef] [PubMed]

38. Loizzo, M.R.; Tundis, R.; Chandrika, U.G.; Abeysekera, A.M.; Menichini, F.; Frega, N.G. Antioxidant and antibacterial activities on foodborne pathogens of Artocarpus heterophyllus Lam. (Moraceae) leaves extracts. J. Food Sci. 2010, 75, M291-M295. [CrossRef]

39. Loizzo, M.R.; Pugliese, A.; Bonesi, M.; Menichini, F.; Tundis, R. Evaluation of chemical profile and antioxidant activity of twenty cultivars from Capsicum annuum, Capsicum baccatum, Capsicum chacoense and Capsicum chinense: A comparison between fresh and processed peppers. LWT-Food Sci. Technol. 2015, 64, 623-631. [CrossRef]

40. Brindisi, M.; Fiorillo, M.; Frattaruolo, L.; Sotgia, F.; Lisanti, M.P.; Cappello, A.R. Cholesterol and mevalonate: Two metabolites involved in breast cancer progression and drug resistance through the ERR $\alpha$ Pathway. Cells 2020, 9, 1819. [CrossRef]

41. Mazzotta, S.; Frattaruolo, L.; Brindisi, M.; Ulivieri, C.; Vanni, F.; Brizzi, A.; Carullo, G.; Cappello, A.R.; Aiello, F. 3-Amino-alkylated indoles: Unexplored green products acting as anti-inflammatory agents. Future Med. Chem. 2019. [CrossRef] [PubMed]

42. Frattaruolo, L.; Fiorillo, M.; Brindisi, M.; Curcio, R.; Dolce, V.; Lacret, R.; Truman, A.W.; Sotgia, F.; Lisanti, M.P.; Cappello, A.R. Thioalbamide, A thioamidated peptide from amycolatopsis alba, affects tumor growth and stemness by inducing metabolic dysfunction and oxidative stress. Cells 2019, 8, 1408. [CrossRef] [PubMed]

43. Fiorillo, M.; Toth, F.; Brindisi, M.; Sotgia, F.; Lisanti, M.P. Deferiprone (DFP) Targets Cancer Stem Cell (CSC) Propagation by Inhibiting Mitochondrial Metabolism and Inducing ROS Production. Cells 2020, 9, 1529. [CrossRef] [PubMed]

44. Perri, F.; Frattaruolo, L.; Haworth, I.; Brindisi, M.; El-magboub, A.; Ferrario, A.; Gomer, C.; Aiello, F.; Adams, J.D. Naturally occurring sesquiterpene lactones and their semi-synthetic derivatives modulate PGE2 levels by decreasing COX2 activity and expression. Heliyon 2019, 5, e01366. [CrossRef] [PubMed]

45. Kavitha, C.V.; Deep, G.; Gangar, S.C.; Jain, A.K.; Agarwal, C.; Agarwal, R. Silibinin inhibits prostate cancer cells- and RANKL-induced osteoclastogenesis by targeting NFATc1, NF-kappaB, and AP-1 activation in RAW264.7 cells. Mol. Carcinog. 2014, 53, 169-180. [CrossRef] 
46. Armentano, B.; Curcio, R.; Brindisi, M.; Mancuso, R.; Rago, V.; Ziccarelli, I.; Frattaruolo, L.; Fiorillo, M.; Dolce, V.; Gabriele, B.; et al. 5-(Carbamoylmethylene)-oxazolidin-2-ones as a promising class of heterocycles inducing apoptosis triggered by increased ROS Levels and mitochondrial dysfunction in breast and cervical cancer. Biomedicines 2020, 8, 35. [CrossRef]

47. Burci, L.M.; da Silva, C.B.; Rondon, J.N.; da Silva, L.M.; de Andrade, S.F.; Miguel, O.G.; de Fatima Gaspari Dias, J.; Miguel, M.D. Acute and subacute (28 days) toxicity, hemolytic and cytotoxic effect of Artocarpus heterophyllus seed extracts. Toxicol. Rep. 2019, 6, 1304-1308. [CrossRef]

48. Crasci, L.; Lauro, M.R.; Puglisi, G.; Panico, A. natural antioxidant polyphenols on inflammation management: Anti-glycation activity vs metalloproteinases inhibition. Crit. Rev. Food Sci. Nutr. 2018, 58, 893-904. [CrossRef]

49. Gilmore, T.D. Introduction to NF-kappaB: Players, pathways, perspectives. Oncogene 2006, 25, 6680-6684. [CrossRef]

50. Nowsheen, S.; Aziz, K.; Kryston, T.B.; Ferguson, N.F.; Georgakilas, A. The interplay between inflammation and oxidative stress in carcinogenesis. Curr. Mol. Med. 2012, 12, 672-680. [CrossRef]

51. Sharma, J.N.; Al-Omran, A.; Parvathy, S.S. Role of nitric oxide in inflammatory diseases. Inflammopharmacology 2007, 15, 252-259. [CrossRef]

52. Dai, C.; Li, B.; Zhou, Y.; Li, D.; Zhang, S.; Li, H.; Xiao, X.; Tang, S. Curcumin attenuates quinocetone induced apoptosis and inflammation via the opposite modulation of Nrf2/HO-1 and NF-kB pathway in human hepatocyte L02 cells. Food Chem. Toxicol. 2016, 95, 52-63. [CrossRef]

53. Lee, S.H.; Kwak, C.H.; Lee, S.K.; Ha, S.H.; Park, J.; Chung, T.W.; Ha, K.T.; Suh, S.J.; Chang, Y.C.; Chang, H.W.; et al. Anti-Inflammatory effect of ascochlorin in LPS-Stimulated RAW 264.7 macrophage cells is accompanied with the down-regulation of iNOS, COX-2 and proinflammatory cytokines through NF-kappaB, ERK1/2, and p38 Signaling Pathway. J. Cell. Biochem. 2016, 117, 978-987. [CrossRef]

54. Johnson, G.L.; Lapadat, R. Mitogen-activated protein kinase pathways mediated by ERK, JNK, and p38 protein kinases. Science 2002, 298, 1911-1912. [CrossRef]

55. Medicherla, K.; Ketkar, A.; Sahu, B.D.; Sudhakar, G.; Sistla, R. Rosmarinus officinalis L. extract ameliorates intestinal inflammation through MAPKs/NF-kappaB signaling in a murine model of acute experimental colitis. Food Funct. 2016, 7, 3233-3243. [CrossRef]

56. Reuter, S.; Gupta, S.C.; Chaturvedi, M.M.; Aggarwal, B.B. Oxidative stress, inflammation, and cancer: How are they linked? Free Radic. Biol. Med. 2010, 49, 1603-1616. [CrossRef]

57. Itharat, A.; Houghton, P.J.; Eno-Amooquaye, E.; Burke, P.J.; Sampson, J.H.; Raman, A. In vitro cytotoxic activity of Thai medicinal plants used traditionally to treat cancer. J. Ethnopharmacol. 2004, 90, 33-38. [CrossRef]

58. Moore, J.; Yousef, M.; Tsiani, E. Anticancer effects of rosemary (Rosmarinus officinalis L.) extract and rosemary extract polyphenols. Nutrients 2016, 8, 731. [CrossRef]

59. Gonzalez-Vallinas, M.; Reglero, G.; Ramirez de Molina, A. Rosemary (Rosmarinus officinalis L.) extract as a potential complementary agent in anticancer therapy. Nutr. Cancer 2015, 67, 1221-1229. [CrossRef]

60. Petiwala, S.M.; Puthenveetil, A.G.; Johnson, J.J. Polyphenols from the Mediterranean herb rosemary (Rosmarinus officinalis) for prostate cancer. Front. Pharmacol. 2013, 4, 29. [CrossRef]

61. Gonzalez-Vallinas, M.; Molina, S.; Vicente, G.; Zarza, V.; Martin-Hernandez, R.; Garcia-Risco, M.R.; Fornari, T.; Reglero, G.; Ramirez de Molina, A. Expression of microRNA-15b and the glycosyltransferase GCNT3 correlates with antitumor efficacy of Rosemary diterpenes in colon and pancreatic cancer. PLoS ONE 2014, 9, e98556. [CrossRef]

62. Tai, J.; Cheung, S.; Wu, M.; Hasman, D. Antiproliferation effect of Rosemary (Rosmarinus officinalis) on human ovarian cancer cells in vitro. Phytomedicine 2012, 19, 436-443. [CrossRef]

63. Gonzalez-Vallinas, M.; Molina, S.; Vicente, G.; Sanchez-Martinez, R.; Vargas, T.; Garcia-Risco, M.R.; Fornari, T.; Reglero, G.; Ramirez de Molina, A. Modulation of estrogen and epidermal growth factor receptors by rosemary extract in breast cancer cells. Electrophoresis 2014, 35, 1719-1727. [CrossRef]

64. Bortner, C.D.; Oldenburg, N.B.; Cidlowski, J.A. The role of DNA fragmentation in apoptosis. Trends Cell Biol. 1995, 5, 21-26. [CrossRef]

65. van Zijl, F.; Krupitza, G.; Mikulits, W. Initial steps of metastasis: Cell invasion and endothelial transmigration. Mutat. Res. 2011, 728, 23-34. [CrossRef] 
66. Obeid, E.; Nanda, R.; Fu, Y.X.; Olopade, O.I. The role of tumor-associated macrophages in breast cancer progression. Int. J. Oncol. 2013, 43, 5-12. [CrossRef]

67. Knowles, H.; Leek, R.; Harris, A.L. Macrophage infiltration and angiogenesis in human malignancy. In Novartis Foundation Symposium; Discussion 200-184, 259-169; John Wiley: Chichester, UK; New York, NY, USA, 2004; Volume 256, pp. 189-200.

68. Ulbricht, C.; Abrams, T.R.; Brigham, A.; Ceurvels, J.; Clubb, J.; Curtiss, W.; Kirkwood, C.D.; Giese, N.; Hoehn, K.; Iovin, R.; et al. An evidence-based systematic review of rosemary (Rosmarinus officinalis) by the Natural Standard Research Collaboration. J. Diet. Suppl. 2010, 7, 351-413. [CrossRef] [PubMed]

69. Fernández-Ochoa, Á.; Borrás-Linares, I.; Pérez-Sánchez, A.; Barrajón-Catalán, E.; González-Álvarez, I.; Arráez-Román, D.; Micol, V.; Segura-Carretero, A. Phenolic compounds in rosemary as potential source of bioactive compounds against colorectal cancer: In situ absorption and metabolism study. J. Funct. Foods 2017, 33, 202-210. [CrossRef]

70. Pérez-Sánchez, A.; Borras-Linares, I.; Barrajón-Catalán, E.; Arráez-Román, D.; Gonzalez-Alvarez, I.; Ibanez, E.; Segura-Carretero, A.; Bermejo, M.; Micol, V. Evaluation of the intestinal permeability of rosemary (Rosmarinus officinalis L.) extract polyphenols and terpenoids in Caco-2 cell monolayers. PLoS ONE 2017, 12, e0172063. [CrossRef]

71. Villalva, M.; Jaime, L.; Aguado, E.; Nieto, J.A.; Reglero, G.; Santoyo, S. Anti-inflammatory and antioxidant activities from the basolateral fraction of Caco-2 cells exposed to a rosmarinic acid enriched extract. J. Agric. Food Chem. 2018, 66, 1167-1174. [CrossRef]

72. Doolaege, E.H.; Raes, K.; De Vos, F.; Verhé, R.; De Smet, S. Absorption, distribution and elimination of carnosic acid, a natural antioxidant from Rosmarinus officinalis, in rats. Plant Foods Hum. Nutr. 2011, 66, 196-202. [CrossRef]

73. Yan, H.; Wang, L.; Li, X.; Yu, C.; Zhang, K.; Jiang, Y.; Wu, L.; Lu, W.; Tu, P.J. High-performance liquid chromatography method for determination of carnosic acid in rat plasma and its application to pharmacokinetic study. Biomed. Chromatogr. 2009, 23, 776-781. [CrossRef]

74. Achour, M.; Saguem, S.; Sarria, B.; Bravo, L.; Mateos, R. Bioavailability and metabolism of rosemary infusion polyphenols using Caco-2 and HepG2 cell model systems. J. Sci. Food Agric. 2018, 98, 3741-3751. [CrossRef]

75. Vamanu, E.; Gatea, F. Correlations between microbiota bioactivity and bioavailability of functional compounds: A mini-review. Biomedicines 2020, 8, 39. [CrossRef] 